\title{
SPATIAL DISTRIBUTION OF SOIL SALINITY USING SALTMED MODEL IN EL-BEHEIRA GOVERNORATE, EGYPT
}

\author{
A. S. El-Hassanin(1), S. A. Abdallah ${ }^{(2)}$, N. M. Saleh ${ }^{(1)}$ and M. S. Abou Kota ${ }^{(2)}$ \\ (1) Institute Of African Research And Studies- Cairo University, Egypt. \\ (2) Soils, Water And Environment Research Institute- Agriculture Research Center, Egypt. \\ Aboukota.m@gmail.com Mohamed_ElSayed1185@yahoo.com
}

Received: Jun. 17, 2016

Accepted: Jun. 22, 2016

\begin{abstract}
Salinization is a common problem for agriculture in dry environments and it has great effect on land soil productivity. Hence, it is of pressing necessity to quantify the spatial distribution of salinity and its changing trend in space and time and ascertain the driving forces thereof. Recently, SALTMED model was used to define the status of moisture and salinity under environmental changes. SALTMED model runs for various irrigation systems and water application strategies, water of different qualities, variety of crops and trees, different nitrogen-based fertilizers and different soil types. The research is aiming to test the reliability and applicability of SALTMED model in a wide range of Egyptian soil types. The model employed in nine examples of soil profiles representing three geomorphological features, different in their physical and chemical properties, using data from the field work and FAO 56. The obtained results generally, showed significant correlation coefficient between the observed and simulated data of salinity and moisture distributions in the soil profiles of all studied experimental soils. The study recommended using SALTMED model to estimate soil moisture and salinity distribution of Egyptian soils to be employed in managing agricultural practices and strategies.
\end{abstract}

Key words: Soil salinity; moisture content; soil texture; SALTMED model.

\section{INTRODUCTION}

Agriculture models have the capability to predict crop development and grain yield as influenced by climatic conditions, soil features and agricultural practices. Modeling is becoming a more and more efficient tool in the management of soil and water resources. Models can provide quantitative estimates of grain yield under different environmental conditions, as well as simulation of water and nutrients balance, also be used to test the crop response to environmental stresses. SALTMED model has been developed for such generic applications. The model employs established water and solute transport, evapotranspiration and crop water uptake equations. The SALTMED model has been calibrated using the drip irrigation water treatment in Syria and Egypt, primarily focused on yield prediction. The SALTMED model has been described in detail in
Ragab, (2002) with some examples of applications. As a matter of convenience for the reader, a summer of the main processes and equations is given here below: The model includes the following key processes: ETo, plant water uptake, water and solute transport under different irrigation systems, drainage and the relationship between crop yield and water use. A brief description of the model calculation is given in the following sections.

\section{- Evapotranspiration.}

Evapotranspiration has been calculated using the Penman-Monteith equation according to Allen et al., (1998) in the following form:

$$
\text { ETo }=\frac{0.408 \Delta(R n-G)+\gamma\left(\frac{900}{T+273}\right) U 2(e s-e a)}{\Delta+\gamma(1+0.34 U 2)}
$$

where, ETo is Evapotranspiration $(\mathrm{mm}$ day $\left.^{-1}\right), \Delta$ is Slop of the Saturated Vapour 
Pressure Curve $\left(\mathrm{kPa}^{0} \mathrm{C}^{-1}\right), R n$ is the Net Radiation (MJ m ${ }^{-2}$ day $^{-1}$ ), $G$ is Soil Heat Flux Density ( $M J ~ m^{-2}$ day $^{-1}$ ), $\gamma$ is Psychometric Constant, $66 \mathrm{~Pa}{ }^{\circ} \mathrm{C}^{-1}, T$ is Mean Daily Air Temperature at $2 \mathrm{~m}$ height $\left(\mathrm{C}^{\circ}\right), U 2$ is Wind Speed at $2 \mathrm{~m}$ High $\left(\mathrm{m} \mathrm{s}^{-1}\right)$, es is Saturated Vapour Pressure at Air Temperature $(\mathrm{kPa})$, $e a$ is Prevailing Vapour Pressure $(\mathrm{kPa})$. The calculated ETo here is for short wellwatered green grass. In the absence of meteorological data (temperature, radiation, wind speed etc.) and if class a pan evaporation data are available, the SALTMED model can use these data to calculate ETo according to Allen et al., (1998) procedure. The model can also calculate the net radiation from solar radiation if net radiation data is not available. The ETc is calculated as:

$E T c=E T o(K c b+K e)$
where, $\quad E T c$ is Crop Evapotranspiration, $K c b$ is $\quad$ Crop Transpiration Coefficient (known also as basal crop coefficient), $\mathrm{Ke}$ is Soil Evaporation Coefficient. These data can be used in the absence of measured values. $\mathrm{Kcb}$ and $\mathrm{Kc}$ are adjusted according for wind speed and relative humidity different from $2 \mathrm{~m} \mathrm{~s}^{-1}$ and $45 \%$, respectively. $\mathrm{Ke}$ is calculated according to Allen et al., (1998). The SALTMED model runs with a daily time step and uses $\mathrm{Kcb}$ and $\mathrm{Ke}$. The latter are not universal and their values differ according to climatic conditions and other factors.

\section{- The actual water uptake in the presence of saline water. \\ The actual water uptake rate:} The formula adopted in the SALTMED model is that suggested by Cardon and Letey, (1992), which determines the water uptake $S\left(d^{-1}\right)$ :

where,

$$
\begin{gathered}
\lambda\left(z_{0}\right)=\frac{5}{3 L} \text { for } z_{0} \leq 0.2 \mathrm{~L} \\
\lambda\left(z_{0}\right)=\frac{25}{12 L} \times\left(1-\frac{\mathrm{z}}{\mathrm{L}}\right) \text { for } 0.2 \mathrm{~L}<\mathrm{z}_{\mathrm{b}} \leq L \\
\lambda\left(\mathrm{z}_{\mathrm{o}}\right)=0.0 \text { for } \mathrm{z}>L
\end{gathered}
$$

where, $S$ determines the Water Uptake $S\left(\mathrm{~d}^{-}\right.$ $\left.{ }^{1}\right), S \max (t)$ is the Maximum Potential Root Water Uptake at the Time, $(z, t)$ is the Vertical Depth Taken Positive Downwards, $\lambda(z, t)$ is the Depth and Time- Dependent Fraction of Total Root Mass, $h$ is the Matric Pressure Head, $\pi$ is the Osmotic Pressure Head, $\pi 50(t)$ is the Time Dependent Value of the Osmotic Pressure at which $S \max (t)$ is Reduced by $50 \%$, $a(t)$ Equals $\pi 50(t) / h 50(t)$ where, $h 50(t)$ is the Matric Pressure at which $S \max (t)$ is reduced by $50 \%$, $\mathrm{L}$ is the Maximum Rooting Depth. The coefficient a ( $t$ ) equals $\pi_{50}(t) /$ $\mathrm{h}_{50}$ (t). The maximum water uptake $S$ is calculated as:

$$
S \max (t)=E T o \times K c b(t)
$$

The values of $h_{50}$ and $\pi_{50}$ can be obtained from experiments or from literature such as (Rhoades et al., 1999).

The rooting depth: The rooting depth was assumed to follow the same course as the crop coefficient $\mathrm{K}_{\mathrm{c}}$. therefore; it has been described by the following equation:

Root depth $(t)=$ root depth min

$$
\begin{aligned}
& +(\text { root depth } \max \\
& - \text { root depth } \min )\} \times \frac{K c(t)}{K c \max }
\end{aligned}
$$

The maximum root depth is available either from direct measurements or from the literature.

The rooting width: Compared with rooting depth, there is a very little information in the literature on lateral extent of the rooting system of field crops over time. Therefore, a simple equation has been suggested as follows: 


$$
\text { Root width }(t)=\left\{\frac{\text { root width }}{\text { root depth }}\right\} \times \text { root depth }(t)
$$

The root width/root depth\} ratio is dependent on the crop and soil type and other factors. It can be obtained either from experimental data or from the literature. During the growth new roots enter new grid cells. The model then calculates the water uptake only from those cells with roots. The model grid cells are identified by 0,1 or 2 . The value of 0 is associated with no roots and 1 for cells fully occupied with roots and 2 for cells with partial root presence. The model produces a data file showing the $2 \mathrm{D}$ root distribution for every day of the simulation.

\section{- Relative and actual crop yield.}

- The relative crop yield (RY): Due to the unique and strong relationship between water uptake and biomass production and hence the final yield, the $R Y$ is estimated as the sum of the actual water uptake over the season divided by the sum of the maximum water uptake (under) no water and salinity stress conditions) as:

$$
R Y=\frac{\sum S(X, z, t)}{\sum \operatorname{Smax}(X, \mathrm{z}, t)}
$$

where, $R Y$ is relative crop yield and $\mathbf{X}, \mathbf{Z}$ are the horizontal and vertical coordinates of each grid cell that contain roots, respectively.

\section{- The actual yield (AY).} by:

The actual yield, AY is simply obtainable

$$
A Y=R Y \times Y \max
$$

where, $A Y$ is the actual yield, $Y \max$ is the maximum yield obtainable in a given region under optimum and stress-free condition.

\section{- Water and solute flow.}

The water flow in soils was described mathematically by the well- known Richard's equation. It is a partial non- linear differential equation, partial in time and space. It is based on two soil physical principles: Darcy's law and mass continuity. Darcy's law states.

$$
\begin{gathered}
q=-K(h) \frac{\delta H}{\delta Z} \\
\psi, \text { as a result } \\
H=\psi+Z
\end{gathered}
$$

where, $q$ is the water flux, $K(h)$ is the hydraulic conductivity as a function of soil water pressure head, $H$ is the hydraulic head, which is the sum of the gravity head, $Z$ and the pressure head. The vertical transient state flow water in a stable and uniform segment of the root zone can be described by a Richard's type equation as:

$$
\frac{\partial \theta}{\partial t}=-\frac{\partial}{\partial Z}\left[K(\theta) \frac{\partial(\psi+Z)}{\partial Z}\right]-S w
$$

where, $\theta$ is Volume wetness, $t$ is the time, $\mathrm{Z}$ is the depth, $K(\theta)$ is the hydraulic conductivity (a function of wetness), $\psi$ is the matrix suction head, $S w$ is the sink term representing extraction by plant roots. The movement of solute in the soil system, its rate and direction depends greatly on the path of water movement but it is also determined by diffusion and hydrodynamic dispersion. If the latter effects are negligible, solute flow by convection can be formulated (Hillel, 1977) as:

$$
J c=q c=\bar{v} \theta c
$$

where, $J c$ is the solute flux density, $q$ is The water flux density of the water, $c$ is the concentration of solute in the flowing water, $\bar{v}$ average velocity of the flow. The rate of a diffusion of a solute $(J d)$ in bulk water at rest is related by (Fick's law) to the concentration gradient as:

$$
J d=D o\left(\frac{\partial c}{\partial x}\right)
$$

where, $J d$ is the rate of a diffusion of a solute, $D$ o The diffusion coefficient in water.It can therefore be expressed according to the following equation: 
El-Hassanin, et al.,

$$
\begin{array}{r}
D s=D o \theta \xi \\
\xi=\xi^{7} /{ }_{3} \theta^{2}{ }_{s}
\end{array}
$$

where, $D s$ is the diffusion coefficient in soil, whereas decreased due to the fact that the liquid phase occupies only a fraction of soil volume and also due to the tortuous nature of the path, $\xi$ is the tortuosity. The tortuosity is an empirical factor smaller than unity which can be expected to decrease with decreasing $\theta$ (Simunek and Suarez, 1994). The convection flux generally causes hydrodynamic dispersion too an effect that depends on the microscopic non-uniformity of flow velocity in the various pores. Thus, a sharp boundary between two miscible solutions becomes increasingly diffuse about the mean position of the front. For such a case the diffusion coefficient has been found by Bresler, (1975) to depend linearly on ( $\bar{U})$ the average flow velocity, as follows:

$$
D h=\alpha \bar{v}
$$

where, $\alpha$ is Empirical coefficient, $\alpha$ is an empirical coefficient. By the combination of the diffusion, the dispersion and the convection the overall flux of solute can be obtained as:

$$
J=-(D h+D s)\left(\frac{\delta c}{\partial x}\right)+\bar{v} \theta c
$$

where, $c$ is The concentration of the solute in the soil solution. If one takes the continuity equation into consideration, onedimensional transient movement of a noninteracting solute in soil can be expressed as:

$$
\frac{\partial(\theta c)}{\partial t}=\frac{\partial}{\partial z}\left(D a \frac{\partial c}{\partial z}\right)-\frac{\partial(q c)}{\partial z}-S s
$$

where, $q$ is The convective flux of the solution, $D a$ is a combined diffusion and dispersion coefficient, $S s$ is a sink term for the solute representing root adsorption/uptake. Under irrigation from a trickle line source, the water and solute transport can be viewed as two-dimensional flow and can be simulated by one of the following:
1) A plane flow model involving the Cartesian co-ordinates $\mathrm{x}$ and $\mathrm{z}$. Plane flow takes place if one considers a set of trickle sources at equal distance and close enough to each other so that their wetting fronts overlap after a short time from the start of the irrigation;

2) A cylindrical flow model described by the cylindrical co-ordinates $r$ and $z$.

Cylindrical flow takes place if one considers the case of a single trickle nozzle or a number of nozzles spaced far enough apart so that overlap of the wetting fronts of the adjacent sources does not take place. For a stable, isotropic and homogeneous porous medium, the two-dimensional flow of water in the soil can be described according to Bresler, (1975) as:

$$
\frac{\partial \theta}{\partial t}=\frac{\partial}{\partial x}\left[K(\theta) \frac{\partial \psi}{\partial x}\right]+\frac{\partial}{\partial z}\left[K(\theta) \frac{\partial(\psi+z)}{\partial z}\right]
$$

where, $x$ is the horizontal co-ordinate, $z$ is the Vertical- ordinate (considered to be positive downward), $K(\theta)$ The hydraulic conductivity of the soil. As isotropic and homogeneous porous media with principal axes of dispersion oriented parallel and perpendicular to the mean direction off low, the hydrodynamic dispersion coefficient $\mathrm{Dij}$ can be defined as follows:

$$
D i j=\lambda T|V| \delta i j+\frac{(\lambda L-\lambda T) V i V j}{|V|+D s(\theta)}
$$

where, $D i j$ is the hydrodynamic dispersion coefficient, $\lambda T$ is the longitudinal dispersivity of the medium, $\lambda T$ is the transversal dispersivity of the medium, $\delta i j$ is Kronecker delta (i.e. $\delta i j=1$ if $i=j$ and $\delta i j=0$ if $i \neq j$ ), $\operatorname{Ds}(\theta)$ is the soil diffusion coefficient, $\mathrm{Vi}$ and $V j$ are the $i$ th and $j$ th components of the average interstitial flow velocity $V$, respectively, $V=\left(\mathrm{V}^{2}{ }_{\mathrm{x}}+\mathrm{V}_{\mathrm{z}}{ }^{2}\right)^{1 / 2}$. If one considers only two dimensions and substituting $D i j$, the salt flow equation becomes: 


$$
\begin{aligned}
\frac{\partial(C \theta)}{\partial t}=\frac{\partial}{\partial x}(D x x & \left.\frac{\partial C}{\partial x}+D x z \frac{\partial C}{\partial z}-q x C\right) \\
& +\frac{\partial}{\partial z}\left(D z z \frac{\partial C}{\partial z}+D z x \frac{\partial C}{\partial z}-q z C\right)
\end{aligned}
$$

In the model, sprinkler, flood and basin irrigation are described by one dimensional flow equations, e.g. Eqs. $\left(\frac{\partial \theta}{\partial t}\right)$ and $\left(\frac{\partial(\theta c)}{\partial t}\right)$. Furrow and trickle line source are described by $2 \mathrm{D}$ equations, e.g. Eqs. $\left(\frac{\partial \theta}{\partial t}\right)$ and $\left(\frac{\partial(C \theta)}{\partial t}\right)$. Trickle point source is described by cylindrical flow equations obtained by replacing $\mathrm{x}$ by the radius $\mathrm{r}$ and rearranging Eqs. $\left(\frac{\partial \theta}{\partial t}\right)$ and $\left(\frac{\partial(c \theta)}{\partial t}\right)$, as given by Bresler, (1975) and Fletcher Armstrong and Wilson, (1983). The water and solute flow equations were solved numerically using a finite difference explicit scheme (Ragab et al., 1984).

\section{- Soil hydraulic parameters.}

Solving the water and solute transport equations requires two soil water relations, namely the soil water content water potential relation and the soil water potential hydraulic conductivity relation. They were taken according to Van Genuchten, (1980). Values of several coefficients of van Genuchten equation such as " $n$ ", " $m$ " constants were calculated based on the relationship between " $n$ ", " $m$ " and the pore size distribution index, "l" (e.g. $n=\lambda+1, m=$ $\lambda / n)$. The later $(\lambda)$ is available in literature and varies according to the soil textural class " $\lambda$ ", values are given in the soil data base and can be edited by the users. Bubbling pressure, soil water content at saturation, field capacity, wilting point, and saturated hydraulic conductivity were given in data base for different soil types and can be edited by users should filed data become available. The data base information was collected from different sources worldwide and reference has been made to the sources.

\section{- Drainage and leaching requirement.}

The model has two options for drainage, either free drainage or an impermeable layer at the bottom of the soil profile. The leaching requirement is calculated as a ratio between the irrigation water salinity to the drainage water salinity if drainage flow was generated (surface irrigation). If drainage flow was not generated (drip), an indication to relative salt accumulation in the root zone is calculated as a ratio between the irrigation water salinity to the mean soil salinity of the root zone. This could be taken as indication for the need to or not to leach if salinity level reaches a critical level in the root zone.

\section{- Data requirements.}

Plant characteristics: these include for each growth stage; the crop coefficient, $K c$, $K c b$, root depth and lateral expansion, crop height and maximum/potential final yield observed in the region under optimum conditions. Soil characteristics: include depth of each soil horizon, saturated hydraulic conductivity, saturated soil water content, salt diffusion coefficient, longitudinal and transversal dispersion coefficient, initial soil moisture and salinity profiles, and tabulated data of soil moisture versus soil water potential and soil moisture versus hydraulic conductivity. Meteorological data: include daily values of temperature (max. and $\min$.), relative humidity, net radiation, wind speed and daily rainfall (Table 1). Water management data: include the date and amount of irrigation water applied and the salinity level of each irrigation application. Model parameters include the number of compartments in both vertical and horizontal direction, tortuosity parameters, diffusion parameters, uptake parameters, position of plant relative to irrigation source and the maximum time step for calculation. The study has been carried out building database for the studied soils had revealed different changes and produce digital maps. Moreover, calibrate and validate the SALTMED model using field data, the 
calibration focused primarily on soil moisture and crops in the field, measured soil salinity.

\section{MATERIALS AND METHODS.}

\section{Description of study area.}

\subsection{Location}

El-Beheira Governorate occupies the main part of the western region of the Nile Delta. It lies on the western side of Rossetta branch; it is bounded to the north by Idku and Maryut lakes, the west by western desert and Cairo- Alexandria Desert Road, and the east by Kafer El-Sheikh, El- Garbiya and El-Monofiya Governorates and to the south by El-Monofiya Governorate. It is bounded by longitudes $30^{\circ} 40^{\prime}$ and $29^{\circ} 50^{\prime} \mathrm{E}$ and latitudes $31^{\circ} 30^{\prime}$ and $30^{\circ} 40^{\prime} \mathrm{N}$, (Map 1).

\subsection{Climate}

The climatic conditions of the study area are typically arid to semi-arid, characterized by along hot dry summer, mild winter with little rainfall, high evaporation with moderately to high relative humidity. With such high annual evapotranspiration both irrigation water and energy costs required for irrigation would be very high. The meteorological data of the study area are presented in Table (1) .

\subsection{Geomorphology}

Nile Delta region covers an area of about 39000 square $\mathrm{km}$. it extends $250 \mathrm{~km}$ from lake Manzala (East) to El-Max, Alexandria (West) and $175 \mathrm{~km}$ in distance from Cairo (South) to lake Burullus (North) and includes the lakes of Maryout, Idku, Burullus and Manzala. The ancient Nile activity would be responsible for the macro- relief and the general slope from South to North towards the sea while the recent Nile activity would lead to the formation of the micro- relief. Surface level of the soil at the main branches or the secondary canals has been higher than valley between them. Within the studied area different geomorphological features have been distinguished (FAO, 1964; El Nahal et al., 1977 and Shata et al., 1978), according to these authors three geomorphic units can be distinguished namely; Alluvial Plain (Recent Nile alluvium); Fluvial- marine plain and Desert plain.

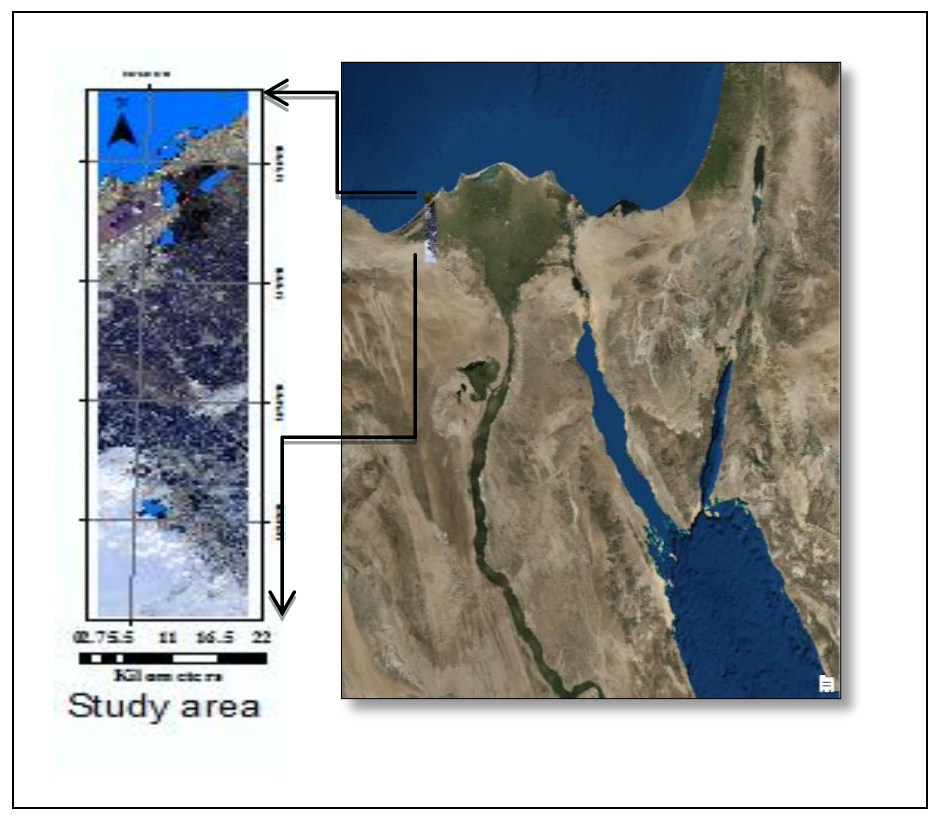

Map (1): Location of the study area. 
Spatial distribution of soil salinity using saltmed model in

Table (1): The meteorological data of the study area (Alexandria station, 2009-2014).

\begin{tabular}{|c|c|c|c|c|c|c|c|}
\hline \multirow{3}{*}{ Month } & \multirow{2}{*}{\multicolumn{2}{|c|}{ Temperature $\left({ }^{\circ} \mathrm{C}\right)$}} & \multirow{3}{*}{$\begin{array}{c}\text { Relative } \\
\text { Humidity (\%) }\end{array}$} & \multirow{3}{*}{$\begin{array}{c}\text { Wind speed } \\
2 \mathrm{~m} \\
(\mathrm{~m} / \mathrm{sec}) \\
\end{array}$} & \multirow{3}{*}{$\begin{array}{c}\text { Rainfall } \\
(\mathrm{mm})\end{array}$} & \multirow{3}{*}{\begin{tabular}{|c|}
$\begin{array}{c}\text { Sunshineduration } \\
(\mathrm{hr})\end{array}$ \\
\end{tabular}} & \multirow{3}{*}{$\begin{array}{c}\mathrm{ET}_{\circ} \\
\text { (mm/day) }\end{array}$} \\
\hline & & & & & & & \\
\hline & Max. & Min. & & & & & \\
\hline Jan. & 23.40 & 10.00 & 68.00 & 2.40 & 17.70 & 11.10 & 20.10 \\
\hline Feb. & 22.00 & 10.19 & 65.00 & 2.70 & 6.50 & 11.00 & 22.30 \\
\hline Mar. & 24.11 & 14.00 & 64.00 & 3.20 & 0.00 & 11.80 & 45.60 \\
\hline Apr. & 25.00 & 13.91 & 62.00 & 2.80 & 0.00 & 12.80 & 74.30 \\
\hline May & 29.90 & 17.50 & 66.00 & 2.90 & 0.00 & 13.60 & 95.70 \\
\hline Jun. & 32.00 & 22.10 & 68.00 & 2.90 & 0.00 & 14.00 & 112.20 \\
\hline Jul. & 34.00 & 24.00 & 67.00 & 2.90 & 0.00 & 14.00 & 120.60 \\
\hline Aug. & 34.50 & 26.00 & 72.00 & 3.10 & 0.00 & 13.20 & 128.00 \\
\hline Sep. & 34.50 & 25.50 & 65.00 & 2.70 & 0.00 & 12.20 & 117.40 \\
\hline Oct. & 31.61 & 23.00 & 64.00 & 2.50 & 6.00 & 11.30 & 99.10 \\
\hline Nov. & 27.50 & 15.80 & 72.00 & 1.80 & 1.00 & 10.40 & 65.00 \\
\hline Dec. & 21.90 & 11.80 & 69.00 & 2.40 & 26.30 & 10.00 & 24.50 \\
\hline
\end{tabular}

\subsection{Hydrological conditions}

Groundwater (mostly recharged by the Nile water) is of relatively limited use in the Valley but is specially used in the desert fringes. Regional information on the hydrological conditions of the northwestern coastal zone of Egypt can be found in several publications such as (Guindy, 1989; Awad et al., 1994 and Shaaban, 2001). The studied area is characterized byextremely low rainfall with high evaporation and evapotranspiration rates. The scanty rainfall is confined to the winter season and rain usually occurs as thunderstorms and showers. Fresh groundwater in the region is believed to originate mainly from Nile delta to east of the investigated area; seepage of the fresh water from the Nile delta may also reach to the west of the studied area, similar results (Sharaky et al., 2007).

\section{Field work description.}

A field survey was done and nine soil profiles, representing Alexandria, Al Beheira and Wadi El Natron districts were conducted. Thus, give the following geomorphological features, which characterizing study area:

- Fluvio- marine plain representing by profiles P1, P2 and P3.

- Nile alluvial plain representing by profiles P4, P5 and P6.

- Desert plain representing by profiles P7, P8 and P9.

Whereas, 36 soil samples representing the different morphological variations throughout the entire profiles were collected and saved for soil analysis.

\section{Laboratory analysis of the selected soil samples.}

The undisturbed soil samples were collected using metal soil cores with height of 2.5 and diameter of $5.0 \mathrm{~cm}$ to determine soil available moisture content and bulk density, but as well as soil tube to measure hydraulic conductivity was measured using soil tube. Disturbed soil samples were airdried, ground and sieved through $2 \mathrm{~mm}$ sieve to obtain the fine earth. 


\subsection{Physical analysis:}

Particle size distribution was estimated using the Pipette Method, described by Piper, (1950) Sodium Hexameta Phosphate was used as a dispersing agent (Richards, 1954). Soil bulk density was determined using metal cores for the undisturbed soil sample, whereas, for the shale platy samples, the paraffin wax method was applied (Black, 1965). The measuring cylinder was used for the single grained sandy soils (Klute, 1986). Hydraulic conductivity coefficient was determined using undisturbed soil cores, using Darcy law (Richards, 1954).

\subsection{Chemical analysis:}

OM was determined using the Walkley and Black Dichromate Acid Oxidation method according to the method outlined by (Jackson, 1967). Soil pH was measured in 1:2.5 soils water suspensions using a $\mathrm{pH}$ meter (MODEL 420A) according to (Van Reeuwijk, 1993). CEC was determined using Sodium Acetate at $\mathrm{pH} 8.2$ for saturation and Ammonium Acetate at $\mathrm{pH} 7.0$ according to (Bower et al., 1952). Gypsum was determined following Schoonover, (1952). $\mathrm{CaCO}_{3}$ content was determined according to Wright, (1939). ESP may be calculated by the following formula according to (Allison et al., 1954).

$$
\mathrm{ESP}=\frac{100(-0.0126+0.01475 \mathrm{SAR})}{1+(-0.0126+0.01475 \mathrm{SAR})}
$$

EC is determined according to Richards, 1948 by using (CONDUCTANCE METER- YSI MODEL 35). $\mathrm{Ca}^{2+}$ and $\mathrm{Mg}^{2+}$ were determined by titration with Ethylenediaminetetraacetate (Versenate) (Reitemeier, 1943). $\mathrm{Na}^{+}$and $\mathrm{K}^{+}$by using Flame Photometer model JENWAY PFP7 (Reitemeier, 1943). $\mathrm{CO}_{3}{ }^{2-}$ and $\mathrm{HCO}_{3}{ }^{-}$by titration with acid (Reitemerir, 1943). $\mathrm{Cl}^{-}$was determined by titration with $\mathrm{AgNO}_{3}$ according to Williams, (1941). The $\mathrm{SO}_{4}{ }^{2-}$ was calculated by subtracting the total soluble anions from the total soluble cations (Page et al., 1982).

\subsection{Nutrients status}

Soluble $\mathrm{NO}_{3}$ and $\mathrm{NH}_{4}$ were determined using a sensitive method described by Keeney and Nelson, (1982) using Kjeldahl methods. Available $\mathrm{P}$ in soil was extracted using $\mathrm{NaHCO}_{3}$ solution $0.5 \mathrm{M}$ at $\mathrm{pH} 8.5$ according to Olsen et al., (1954), and was detected using Spectrophotometer at 880 $\mathrm{nm}$ (SPECTRONIC 21D). Available $\mathrm{K}^{+}$in soil was extracted using $1 \mathrm{~N} \quad \mathrm{NH}_{4} \mathrm{CH}_{3} \mathrm{CO}_{2}$ solution at $\mathrm{pH} 7$ according to Page et al., (1982), and was detected using Flame Spectrophotometer model JENWAY PFP7. Available forms of $\mathrm{Fe}, \mathrm{Mn}, \mathrm{Zn}$ and $\mathrm{Cu}$ were extracted using DTPA method. The extracting solution was consisting of $0.005 \mathrm{M}$ DTPA, $\quad 0.01 \mathrm{M} \quad \mathrm{CaCl}_{2}$ and $0.1 \mathrm{M}$ (Triethanolamine) at $\mathrm{pH}$ adjusted to 7.3 using $\mathrm{HCl}$ (1:1) according to Follet and Lindsay, (1971), determined with Atomic Absorption Spectrophotometer (MODEL GBC 932).

\section{Brief description of the SALTMED model.}

The SALTMED model (Ragab, 2002), was designed to be generic, physically based, and friendly to use andincludes a number of physical processes acting simultaneously under field conditions, was evaluated in experimental work. The model runs under all irrigation systems, and incorporates evapotranspiration, plant water uptake, water and solute transport, soil moisture and soil salinity, based on a relationship between simulated and observed results of the soils in Egypt. The study sites were chosen to cover different crops, irrigation systems and soil types. 


\section{RESULTS AND DISCUSSION. 1. Soil characterize of the study area.}

Soil texture is considered one of most important soil criteria affecting soil behavior and land management and it influences a number of physical and chemical soil characteristics. The particle size distribution of fluvial marine plain soils showed that the soil had medium to fine textured being loamy sand, sandy loam, loamy and clay loam. Also, the soils of the Nile alluvial plain were found to be heavy textured soils ranging between clay, silt and silt clay. The desert formation soils had a sandy texture. Bulk density is an indicator of soil compaction and soil health. The bulk density values were 1.26 to $1.65 \mathrm{~g} \mathrm{~cm}^{-3}$ for fluvial marine soils; 1.21 to $1.41 \mathrm{~g} \mathrm{~cm}^{-3}$ for Nile alluvial plain soils and 1.62 to $1.83 \mathrm{~g} \mathrm{~cm}^{-3}$ for desert formation soils. The hydraulic conductivity is mainly affected by soil texture, structure soil tillage and biological environmental activity such as roots decay as well as numerous small cracks (Aly, 2005). The results of soil hydraulic conductivity recorded 2.417 to $17.251 \mathrm{~cm} \mathrm{~h}^{-1}$ in fluvial marine soils, 0.077 to $0.275 \mathrm{~cm} \mathrm{~h}^{-1}$ in Nile alluvial plain soils and 15.666 to $17.079 \mathrm{~cm} \mathrm{~h}^{-1}$ in desert formation soils, (Table 2).

Soil organic matter is a main source for many elements in soil and helps to maintain the aggregates of soils as well as increase resistance to erosion. The determined $\mathrm{OM}$ contents of the soils under investigation fluctuated in fluvial marine plain from 0.22 to $5.69 \%$; from 0.22 to $3.28 \%$ in Nile alluvial plain and from 0.07 to $1.34 \%$ in desert formation, (Table 2). As lime content of the soils is concerned it is worth to mention that the study area are mainly developed on; Holocene deposits of coastal sand dunes lagoons, alluvial deposits, Pleistocene Oolitic limestone ridges and old lagoons deposits, (Table 2). Consequently, data in table (2) reveal that $\mathrm{CaCO}_{3}$ content of the fluvial-marine plain soils ranged from 11.07 to $86.79 \%$; Nile alluvial plain from 12.86 to $73.75 \%$ and desert formation from 0.29 to $7.83 \%$. Data illustrated in table (2) show that gypsum content range between 0.11 and $43.13 \%$ for fluvial- marine plain, between 0.82 and $34.3 \%$ for the Nile alluvial deposits and between 3.08 and $18.39 \%$ for desert formation soils. Soil texture is one of parameters that have great influence on CEC values. The CEC values of the studied soils differs and coincides well with soil texture where, in fluvial-marine soils varied widely from 6.65 and $29.56 \mathrm{Cmolc} \mathrm{kg}^{-1}$ as well as in Nile alluvial from 14.64 to 37.00 $\mathrm{Cmolc} \mathrm{kg}^{-1}$ while in desert soils were ranging between 4.51 and $5.00 \mathrm{Cmolc} \mathrm{kg}^{-1}$.

The soil pH is crucial for the healthy plant growth as it affect the amount of nutrient available to plants (Nur et al., 2014). The obtained data showed that soil $\mathrm{pH}$ varied from 7.82 to 8.23 in fluvial marine; from 7.80 to 7.97 in Nile alluvial plain and from 7.79 to 8.18 in desert formation. Data in table (3) revealed that soil salinity values in fluvial marine plain ranged between 2.23 and 8.41 $\mathrm{dS} \mathrm{m}^{-1}$, between 0.57 and $2.48 \mathrm{dS} \mathrm{m}^{-1}$ in Nile alluvial plain, and from 0.74 to $14.48 \mathrm{dS}$ $\mathrm{m}^{-1}$ in desert formation. The dominant soluble cations were $\mathrm{Na}^{+}, \mathrm{Ca}^{+2}$ and $\mathrm{Mg}^{+2}$ and the content of $\mathrm{K}^{+}$was rather low in a descending order, while soluble anions were dominated by $\mathrm{Cl}^{-}$and $\mathrm{SO}_{4}{ }^{-2}$. The pattern of soluble anions and cations indicated that $\mathrm{NaCl}, \mathrm{Na}_{2} \mathrm{SO}_{4}, \mathrm{MgSO}_{4}$ and $\mathrm{CaCl}_{2} / \mathrm{MgCl}_{2}$ were the dominant soluble salts of the studied soils in descending order. The ESP ranged from 7.16 to 19.13 in fluvial-marine plain, from 1.88 to 7.03 in Nile alluvial plain and from 0.33 to 14.13 in desert plain (Table $3)$. 
El-Hassanin, et al.,

Table (2): Some soil physical and chemical properties for the studied area.

\begin{tabular}{|c|c|c|c|c|c|c|c|c|c|c|c|c|}
\hline \multirow{2}{*}{ t. } & \multirow{2}{*}{ 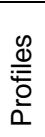 } & \multirow{2}{*}{$\begin{array}{l}\text { Depth } \\
\text { (cm) }\end{array}$} & \multicolumn{3}{|c|}{$\begin{array}{c}\text { Particle size } \\
\text { distribution (\%) }\end{array}$} & \multirow{2}{*}{ 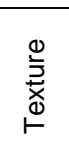 } & \multirow{2}{*}{$\begin{array}{c}\text { Bulk } \\
\text { density } \\
\left(\mathrm{g} \mathrm{cm}^{-3}\right)\end{array}$} & \multirow{2}{*}{$\begin{array}{l}\text { Hydraulic } \\
\text { conductivity } \\
\left(\mathrm{cm} \mathrm{h}^{-1}\right)\end{array}$} & \multirow{2}{*}{$\begin{array}{l}\mathrm{OM} \\
(\%)\end{array}$} & \multirow{2}{*}{$\begin{array}{c}\mathrm{CaCO}_{3} \\
(\%)\end{array}$} & \multirow{2}{*}{$\begin{array}{c}\text { Gypsum } \\
(\%)\end{array}$} & \multirow{2}{*}{$\begin{array}{c}\text { CEC } \\
\left(\mathrm{Cmol}_{\mathrm{c}} \mathrm{kg}^{-1}\right)\end{array}$} \\
\hline & & & Sand & Silt & Clay & & & & & & & \\
\hline \multirow{3}{*}{ 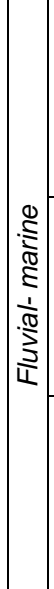 } & P1 & $\begin{array}{c}0-20 \\
20-45 \\
45-60 \\
60-80\end{array}$ & $\begin{array}{l}85.25 \\
82.75 \\
53.50 \\
57.49\end{array}$ & $\begin{array}{c}10.09 \\
8.41 \\
45.53 \\
36.56\end{array}$ & $\begin{array}{l}4.66 \\
8.84 \\
0.97 \\
5.95\end{array}$ & $\begin{array}{l}\text { LS } \\
\text { LS } \\
\text { SL } \\
\text { SL }\end{array}$ & $\begin{array}{l}1.41 \\
1.42 \\
1.43 \\
1.43\end{array}$ & $\begin{array}{l}2.417 \\
6.450 \\
6.922 \\
7.751\end{array}$ & $\begin{array}{l}5.61 \\
5.69 \\
4.77 \\
5.21\end{array}$ & $\begin{array}{l}26.86 \\
86.99 \\
21.93 \\
24.97\end{array}$ & $\begin{array}{c}12.92 \\
19.54 \\
2.03 \\
1.55\end{array}$ & $\begin{array}{c}7.55 \\
8.00 \\
9.13 \\
11.45\end{array}$ \\
\hline & P2 & $\begin{array}{c}0.25 \\
25-55 \\
55-70 \\
70-90\end{array}$ & $\begin{array}{l}78.72 \\
80.96 \\
79.95 \\
33.97\end{array}$ & $\begin{array}{l}19.14 \\
17.31 \\
16.41 \\
41.31\end{array}$ & $\begin{array}{c}2.14 \\
1.73 \\
3.64 \\
24.72\end{array}$ & $\begin{array}{c}\text { LS } \\
\text { LS } \\
\text { LS } \\
\text { L }\end{array}$ & $\begin{array}{l}1.45 \\
1.65 \\
1.41 \\
1.31\end{array}$ & $\begin{array}{l}6.103 \\
6.314 \\
7.006 \\
7.919\end{array}$ & $\begin{array}{l}5.69 \\
5.01 \\
4.77 \\
4.17\end{array}$ & $\begin{array}{l}53.70 \\
45.00 \\
56.09 \\
32.53\end{array}$ & $\begin{array}{l}2.01 \\
0.15 \\
0.11 \\
0.17\end{array}$ & $\begin{array}{c}8.00 \\
6.65 \\
7.14 \\
15.15\end{array}$ \\
\hline & P3 & $\begin{array}{c}0-25 \\
25-60 \\
60-80 \\
80-130\end{array}$ & $\begin{array}{l}37.92 \\
37.74 \\
67.50 \\
77.50\end{array}$ & $\begin{array}{c}30.01 \\
28.55 \\
3.71 \\
19.13\end{array}$ & $\begin{array}{c}32.07 \\
33.71 \\
28.79 \\
3.37\end{array}$ & $\begin{array}{l}\mathrm{CL} \\
\mathrm{CL} \\
\mathrm{SC} \\
\mathrm{LS}\end{array}$ & $\begin{array}{l}1.37 \\
1.34 \\
1.26 \\
1.41\end{array}$ & $\begin{array}{c}16.452 \\
17.251 \\
3.650 \\
7.981\end{array}$ & $\begin{array}{l}5.69 \\
1.01 \\
0.28 \\
0.22\end{array}$ & $\begin{array}{l}44.63 \\
29.88 \\
17.40 \\
11.07\end{array}$ & $\begin{array}{c}41.40 \\
43.13 \\
0.80 \\
4.20\end{array}$ & $\begin{array}{c}24.65 \\
26.17 \\
29.56 \\
8.00\end{array}$ \\
\hline \multirow{3}{*}{ 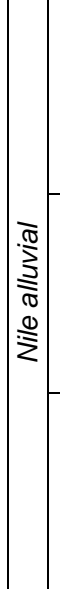 } & P4 & $\begin{array}{c}0-25 \\
25-60 \\
60-100 \\
100- \\
130\end{array}$ & $\begin{array}{c}6.23 \\
5.50 \\
13.40 \\
10.12\end{array}$ & $\begin{array}{l}12.00 \\
43.00 \\
24.30 \\
29.94\end{array}$ & $\begin{array}{l}81.77 \\
51.50 \\
62.30 \\
59.94\end{array}$ & $\begin{array}{c}\mathrm{C} \\
\mathrm{Si} \mathrm{C} \\
\mathrm{C} \\
\mathrm{C}\end{array}$ & $\begin{array}{l}1.34 \\
1.21 \\
1.37 \\
1.38\end{array}$ & $\begin{array}{l}0.187 \\
0.275 \\
0.112 \\
0.077\end{array}$ & $\begin{array}{l}3.28 \\
3.26 \\
2.81 \\
2.19\end{array}$ & $\begin{array}{l}43.88 \\
32.90 \\
36.68 \\
55.98\end{array}$ & $\begin{array}{c}4.52 \\
34.30 \\
5.81 \\
4.54\end{array}$ & $\begin{array}{l}36.45 \\
30.14 \\
37.00 \\
36.64\end{array}$ \\
\hline & $\begin{array}{l}P \\
5\end{array}$ & $\begin{array}{c}0-25 \\
25-45 \\
45-70 \\
70-130\end{array}$ & $\begin{array}{l}8.69 \\
8.69 \\
8.14 \\
8.42\end{array}$ & $\begin{array}{l}19.75 \\
15.00 \\
89.86 \\
29.54\end{array}$ & $\begin{array}{c}71.56 \\
76.31 \\
2.00 \\
62.04\end{array}$ & $\begin{array}{l}\mathrm{C} \\
\mathrm{C} \\
\mathrm{Si} \\
\mathrm{C}\end{array}$ & $\begin{array}{l}1.35 \\
1.36 \\
1.25 \\
1.37\end{array}$ & $\begin{array}{l}0.187 \\
0.132 \\
0.251 \\
0.101\end{array}$ & $\begin{array}{l}1.31 \\
0.18 \\
0.39 \\
0.24\end{array}$ & $\begin{array}{l}56.73 \\
12.86 \\
54.84 \\
52.95\end{array}$ & $\begin{array}{l}2.89 \\
3.92 \\
3.93 \\
0.82\end{array}$ & $\begin{array}{l}37.00 \\
36.58 \\
14.64 \\
34.32\end{array}$ \\
\hline & $\begin{array}{l}P \\
6\end{array}$ & $\begin{array}{c}0-25 \\
25-50 \\
50-70 \\
70-120\end{array}$ & $\begin{array}{c}10.57 \\
13.90 \\
9.30 \\
9.04\end{array}$ & $\begin{array}{l}31.93 \\
21.35 \\
33.60 \\
37.48\end{array}$ & $\begin{array}{l}57.50 \\
64.75 \\
57.10 \\
53.48\end{array}$ & $\begin{array}{l}C \\
C \\
C \\
C\end{array}$ & $\begin{array}{l}1.34 \\
1.36 \\
1.38 \\
1.41\end{array}$ & $\begin{array}{l}0.140 \\
0.136 \\
0.124 \\
0.097\end{array}$ & $\begin{array}{l}1.26 \\
0.78 \\
1.01 \\
0.22\end{array}$ & $\begin{array}{l}52.19 \\
73.75 \\
29.50 \\
35.55\end{array}$ & $\begin{array}{l}2.90 \\
3.25 \\
2.56 \\
2.36\end{array}$ & $\begin{array}{l}33.95 \\
30.81 \\
35.72 \\
34.59\end{array}$ \\
\hline \multirow{3}{*}{ 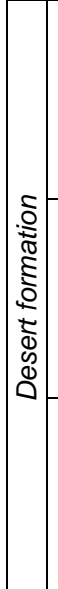 } & $\begin{array}{l}P \\
7\end{array}$ & $\begin{array}{c}0-25 \\
25-40 \\
40-70 \\
70-110\end{array}$ & $\begin{array}{l}92.32 \\
90.18 \\
89.65 \\
89.74\end{array}$ & $\begin{array}{l}3.57 \\
4.58 \\
6.10 \\
4.14\end{array}$ & $\begin{array}{l}4.11 \\
5.24 \\
4.25 \\
6.12\end{array}$ & $\begin{array}{l}S \\
S \\
S \\
S\end{array}$ & $\begin{array}{l}1.69 \\
1.70 \\
1.70 \\
1.83\end{array}$ & $\begin{array}{l}16.752 \\
15.666 \\
16.714 \\
16.893\end{array}$ & $\begin{array}{l}1.34 \\
0.07 \\
0.21 \\
0.64\end{array}$ & $\begin{array}{l}5.72 \\
7.83 \\
6.20 \\
1.45\end{array}$ & $\begin{array}{l}3.28 \\
3.30 \\
5.17 \\
5.73\end{array}$ & $\begin{array}{l}4.51 \\
5.00 \\
5.00 \\
5.00\end{array}$ \\
\hline & $\begin{array}{l}P \\
8\end{array}$ & $\begin{array}{c}0-25 \\
25-55 \\
55-110 \\
110- \\
140\end{array}$ & $\begin{array}{l}92.85 \\
95.32 \\
94.29 \\
95.55\end{array}$ & $\begin{array}{l}2.54 \\
2.36 \\
3.00 \\
2.59\end{array}$ & $\begin{array}{l}4.61 \\
2.32 \\
2.71 \\
1.86\end{array}$ & $\begin{array}{l}S \\
S \\
S \\
S\end{array}$ & $\begin{array}{l}1.70 \\
1.71 \\
1.80 \\
1.85\end{array}$ & $\begin{array}{l}17.014 \\
17.000 \\
17.014 \\
17.079\end{array}$ & $\begin{array}{l}0.78 \\
0.07 \\
0.64 \\
0.78\end{array}$ & $\begin{array}{l}0.73 \\
0.58 \\
0.97 \\
0.29\end{array}$ & $\begin{array}{c}16.18 \\
8.55 \\
3.08 \\
18.39\end{array}$ & $\begin{array}{l}4.91 \\
4.83 \\
3.19 \\
5.00\end{array}$ \\
\hline & $\begin{array}{l}\mathrm{P} \\
9\end{array}$ & $\begin{array}{c}0-20 \\
20-40 \\
40-80 \\
80-130\end{array}$ & $\begin{array}{l}93.43 \\
92.95 \\
92.86 \\
93.24\end{array}$ & $\begin{array}{l}3.16 \\
2.57 \\
2.56 \\
2.98\end{array}$ & $\begin{array}{l}3.41 \\
4.48 \\
4.58 \\
3.78\end{array}$ & $\begin{array}{l}S \\
S \\
S \\
S\end{array}$ & $\begin{array}{l}1.62 \\
1.68 \\
1.79 \\
1.81\end{array}$ & $\begin{array}{l}17.000 \\
16.781 \\
16.777 \\
16.809\end{array}$ & $\begin{array}{l}0.50 \\
0.07 \\
1.34 \\
1.34\end{array}$ & $\begin{array}{l}0.97 \\
5.91 \\
3.39 \\
1.94\end{array}$ & $\begin{array}{l}3.58 \\
3.76 \\
3.37 \\
3.65\end{array}$ & $\begin{array}{l}4.94 \\
4.83 \\
5.00 \\
4.67\end{array}$ \\
\hline
\end{tabular}

$\mathrm{LS}=$ Loamy Sand, SL= Sandy Loam, L= Loam, CL= Clay Loam, SC= Sandy Clay, C= Clay, Si C= Silt Clay, Si= Silt, $S=$ Sandy. 
Table (3): Electric conductivity, soil- pH, soluble cations and anions and exchangeable sodium percentage for the studied area.

\begin{tabular}{|c|c|c|c|c|c|c|c|c|c|c|c|c|}
\hline \multirow{2}{*}{ 蒙 } & \multirow{2}{*}{ 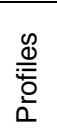 } & \multirow{2}{*}{$\begin{array}{l}\text { Depth } \\
(\mathrm{cm})\end{array}$} & \multirow{2}{*}{$\begin{array}{c}\mathrm{pH} \\
1: 2.5\end{array}$} & \multirow{2}{*}{$\begin{array}{c}E C \\
(\mathrm{dS} / \mathrm{m})\end{array}$} & \multicolumn{4}{|c|}{$\begin{array}{c}\text { Soluble cations } \\
\left(\mathrm{mmolc} \mathrm{L}^{-1}\right)\end{array}$} & \multicolumn{3}{|c|}{$\begin{array}{l}\text { Soluble anions } \\
\left(\mathrm{mmolc} \mathrm{L}^{-1}\right)\end{array}$} & \multirow{2}{*}{ ESP } \\
\hline & & & & & $\mathrm{Ca}^{2+}$ & $\mathrm{Mg}^{2+}$ & $\mathrm{K}^{+}$ & $\mathrm{Na}^{+}$ & $\mathrm{Cl}^{-}$ & $\mathrm{HCO}_{3}^{-}$ & $\mathrm{SO}_{4}{ }^{2-}$ & \\
\hline \multirow{12}{*}{ 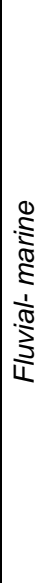 } & \multirow{4}{*}{ P1 } & \multirow{4}{*}{$\begin{array}{c}0-20 \\
20-45 \\
45-60 \\
60-80\end{array}$} & 7.91 & \multirow{4}{*}{$\begin{array}{l}8.41 \\
6.63 \\
4.56 \\
3.99\end{array}$} & 21.0 & 3.61 & 1.09 & 59.3 & 30.0 & 2.00 & 53.0 & 19.13 \\
\hline & & & 7.82 & & 20.0 & 1.57 & 1.05 & 43.5 & 25.0 & 2.80 & 38.3 & 15.47 \\
\hline & & & 7.97 & & 10.0 & 1.16 & 0.84 & 33.4 & 17.5 & 1.80 & 26.1 & 16.40 \\
\hline & & & 7.97 & & 9.0 & 2.66 & 0.84 & 27.3 & 14.0 & 1.60 & 24.2 & 13.38 \\
\hline & \multirow{4}{*}{ P2 } & \multirow{4}{*}{$\begin{array}{c}0.25 \\
25-55 \\
55-70 \\
70-90\end{array}$} & 7.98 & \multirow{4}{*}{$\begin{array}{l}3.02 \\
4.08 \\
2.23 \\
3.14\end{array}$} & 8.0 & 2.97 & 1.23 & 17.8 & 10.0 & 2.40 & 17.6 & 9.06 \\
\hline & & & 7.85 & & 11.0 & 2.75 & 1.16 & 25.8 & 16.5 & 2.00 & 22.2 & 11.71 \\
\hline & & & 8.23 & & 5.0 & 2.35 & 0.65 & 14.1 & 7.5 & 3.40 & 11.2 & 8.73 \\
\hline & & & 7.88 & & 11.0 & 3.41 & 0.51 & 16.3 & 4.0 & 1.00 & 26.2 & 7.16 \\
\hline & \multirow{4}{*}{ P3 } & \multirow{4}{*}{$\begin{array}{c}0-25 \\
25-60 \\
60-80 \\
80-130\end{array}$} & 7.82 & \multirow{4}{*}{$\begin{array}{l}3.95 \\
4.39 \\
3.81 \\
3.71\end{array}$} & 13.0 & 4.00 & 1.10 & 21.3 & 10.0 & 2.60 & 26.8 & 8.67 \\
\hline & & & 7.85 & & 16.0 & 5.19 & 1.02 & 21.6 & 11.5 & 1.40 & 30.9 & 7.88 \\
\hline & & & 7.90 & & 13.0 & 4.40 & 0.91 & 19.5 & 8.5 & 2.60 & 26.7 & 7.83 \\
\hline & & & 7.87 & & 14.0 & 2.25 & 0.96 & 19.8 & 8.0 & 1.60 & 27.4 & 8.25 \\
\hline \multirow{12}{*}{$\begin{array}{l}\stackrel{0}{3} \\
\frac{\pi}{\sqrt{2}} \\
\stackrel{0}{\Sigma}\end{array}$} & \multirow{4}{*}{ P4 } & \multirow{4}{*}{$\begin{array}{c}0-25 \\
25-60 \\
60-100 \\
100-130\end{array}$} & 7.86 & 1.94 & 8.0 & 1.19 & 0.86 & 9.3 & 4.0 & 3.00 & 12.4 & 4.90 \\
\hline & & & 7.80 & 2.48 & 8.0 & 3.08 & 0.86 & 12.8 & 3.0 & 2.00 & 19.7 & 7.03 \\
\hline & & & 7.90 & 2.41 & 8.5 & 2.49 & 0.51 & 12.6 & 4.5 & 1.20 & 18.4 & 6.26 \\
\hline & & & 7.97 & 2.13 & 9.0 & 1.93 & 0.47 & 9.9 & 3.0 & 1.40 & 16.9 & 4.74 \\
\hline & \multirow{4}{*}{ P5 } & \multirow{4}{*}{$\begin{array}{c}0-25 \\
25-45 \\
45-70 \\
70-130\end{array}$} & 7.83 & 0.72 & 1.5 & 1.11 & 0.30 & 4.1 & 2.0 & 3.40 & 1.6 & 3.89 \\
\hline & & & 7.97 & 0.85 & 1.0 & 1.44 & 0.67 & 5.3 & 2.5 & 3.80 & 2.1 & 5.53 \\
\hline & & & 7.86 & 0.98 & 2.0 & 1.09 & 0.51 & 6.2 & 2.5 & 2.80 & 4.5 & 5.76 \\
\hline & & & 7.86 & 0.83 & 1.5 & 3.13 & 0.37 & 3.2 & 2.5 & 3.00 & 2.7 & 5.91 \\
\hline & & $0-25$ & 7.90 & 0.71 & 2.0 & 0.62 & 0.28 & 4.2 & 2.0 & 3.60 & 1.5 & 4.00 \\
\hline & DR & $25-50$ & 7.90 & 0.62 & 2.0 & 0.95 & 0.35 & 2.9 & 3.2 & 3.50 & 0.5 & 2.23 \\
\hline & Po & $\begin{array}{c}50-70 \\
70-120\end{array}$ & 7.97 & 0.57 & 1.5 & 1.44 & 0.16 & 2.6 & 3.4 & 2.50 & 0.2 & 1.88 \\
\hline & & & 7.96 & 0.96 & 2.0 & 3.76 & 0.09 & 3.7 & 3.0 & 2.20 & 4.4 & 1.92 \\
\hline & & $0-25$ & 7.86 & 4.95 & 20.0 & 12.55 & 3.06 & 13.8 & 10.0 & 4.00 & 35.4 & 3.65 \\
\hline & $\mathrm{P} 7$ & $25-40$ & 7.89 & 3.58 & 17.5 & 10.52 & 2.07 & 5.6 & 8.0 & 4.40 & 23.3 & 0.96 \\
\hline & $P T$ & $\begin{array}{c}40-70 \\
70-110\end{array}$ & 7.94 & 4.83 & 29.0 & 7.55 & 1.90 & 9.6 & 11.0 & 4.00 & 33.0 & 2.02 \\
\hline & & & 8.00 & 2.75 & 9.0 & 5.00 & 1.37 & 11.9 & 6.5 & 2.80 & 18.0 & 5.09 \\
\hline 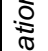 & & & 7.79 & 14.48 & 43.5 & 26.55 & 3.62 & 71.1 & 60.5 & 7.40 & 76.9 & 14.13 \\
\hline है & PQ & 25-55 & 7.92 & 7.24 & 21.0 & 5.55 & 2.55 & 43.1 & 18.5 & 5.40 & 48.3 & 13.94 \\
\hline$\frac{5}{5}$ & ro & & 8.01 & 2.50 & 10.5 & 10.00 & 1.05 & 3.45 & 3.0 & 2.20 & 19.8 & 0.33 \\
\hline $\begin{array}{l}\infty \\
0 \\
0 \\
0\end{array}$ & & & 7.92 & 2.17 & 8.0 & 7.55 & 0.84 & 5.2 & 3.0 & 2.60 & 16.0 & 1.46 \\
\hline & & & 8.10 & 1.60 & 8.0 & 2.00 & 1.85 & 4.2 & 2.5 & 4.00 & 9.6 & 1.49 \\
\hline & & $20-40$ & 8.18 & 0.74 & 3.5 & 1.00 & 0.97 & 1.8 & 1.5 & 4.00 & 1.8 & 0.51 \\
\hline & P9 & $40-80$ & 8.13 & 1.15 & 5.5 & 1.50 & 1.39 & 3.1 & 1.5 & 2.80 & 7.2 & 0.59 \\
\hline & & & 8.04 & 2.38 & 10.5 & 9.55 & 1.74 & 1.9 & 1.5 & 3.20 & 19.0 & 0.38 \\
\hline
\end{tabular}


Macronutrients are of great importance in controlling yield of most crops. Data in table (4) demonstrated the vertical distribution of the available $\mathrm{N}$ of the studied soil profiles, where in fluvial- marine plain the $\mathrm{NH}_{4}{ }^{+}$ranged from 15.53 to $39.15 \mathrm{mg} \mathrm{kg}^{-1}$ and $\mathrm{NO}_{3}{ }^{-}$from41.90 to $225.45 \mathrm{mg} \mathrm{kg}^{-1}$, while in Nile alluvial plain $\mathrm{NH}_{4}{ }^{+}$amounted from 10.90 to $46.58 \mathrm{mg} \mathrm{kg}^{-1}$ and $\mathrm{NO}_{3}^{-}$from 51.24 to $123.52 \mathrm{mg} \mathrm{kg}^{-1}$. Moreover, the available $\mathrm{N}$ content in desert plain were in form of $\mathrm{NH}_{4}{ }^{+}$ ranging between 12.10 and $40.45 \mathrm{mg} \mathrm{kg}$ ${ }^{1}$ and in the form of $\mathrm{NO}_{3}{ }^{-}$varied from 24.03 to $49.10 \mathrm{mg} \mathrm{kg}^{-1}$. Similar results had been reported by Abou Kota, (2012). Data of table (4) showed the vertical distribution of the available $\mathrm{P}$ of the studied soil profiles, where in fluvial- marine plain $P$ ranged between 14.5 and $21.7 \mathrm{mg} \mathrm{kg}^{-1}$, in Nile alluvial plain amounted from 10.9 to $20.9 \mathrm{mg} \mathrm{kg}^{-1}$ while, in desert plain $\mathrm{P}$ was ranging from 18.1 to 29.6 $\mathrm{mg} \mathrm{kg}$. The amount of available $\mathrm{K}$ in different studied soil sediments, was in fluvial- marine plain ranged between 156.00 and $336.96 \mathrm{mg} \mathrm{kg}^{-1}$, in Nile alluvial plain between 130.26 and $421.20 \mathrm{mg} \mathrm{kg}^{-1}$ and in desert plain between 143.52 and $262.22 \mathrm{mg}$ $\mathrm{kg}^{-1}$.

The available of micronutrients is particularly sensitive to changes in soil environment. In table (4) data showed that the values of available $\mathrm{Fe}$ in fluvial- marine plain, Nile alluvial plain and desert plain ranged from 2.00 to $9.81,3.47$ to 9.81 and 0.26 to $2.00 \mathrm{mg} \mathrm{kg}^{-1}$, respectively. The amount of DTPA extractable $\mathrm{Mn}$ ranged from 0.70 to $3.22,0.69$ to 3.24 and 0.20 to $0.50 \mathrm{mg} \mathrm{kg}^{-1}$ in fluvial- marine plain, Nile alluvial plain and desert plain, respectively. Also, the available $\mathrm{Zn}$ in fluvial-marine plain, Nile alluvial plain and desert plain ranged from 0.17 to $0.45,0.18$ to 0.44 and 0.11 to $0.23 \mathrm{mg} \mathrm{kg}^{-1}$, respectively. The available amounts of $\mathrm{Cu}$ in the different studied soils showed ranged from 0.67 to $4.74,1.23$ to 3.00 and 0.36 to $1.24 \mathrm{mg} \mathrm{kg}^{-1}$ in fluvial marine plain, Nile alluvial plain and desert plain, respectively.

\subsection{Application of SALTMED Model.}

The model outputs are given as text and graphical files. These include vertical distribution of soil moisture, soil salinity, and relative salt concentration and nitrogen profiles, in addition to salinity indicators plot in agricultural season. The results illustrated the good agreement that was found between observed and simulated values for soil salinity and soil moisture; under climate, soil characteristics including the thickness of each soil layer, saturated hydraulic conditions and different saturated soil water content, the soil database that was built in SALTMED. The results indicated that the soil salinity levels for fluvial marine profiles became greater than salinity of irrigation water especially in the surface and subsurface layers. Also, the soil salinity levels for Nile alluvial profiles became greater than salinity of irrigation water especially the surface and subsurface. Too, the soil salinity of desert formation profiles is greater than salinity of irrigation water under different irrigation systems. Future development of the SALTMED model could take into account the impact of both salinity of irrigation water and nutrients on yield. The model successfully illustrated the effect of the irrigation system, the soil type, the salinity level of irrigation water on soil moisture and salinity distribution. The model was able to simulate successfully the soil moisture and salinity profiles to give a sight of what will happen in the soil by using different arguments in the farm and the effect of them on the yield to help the farm managers or farmers for deciding theproper amounts of irrigation water and fertilizers, because the right decisions will reduce costs and increase the income. Simulated and observed results under different irrigation system were compared as shown in figures (1 and 2) and table (5). 
Table (4): Available contents of macro and micro nutrients for the studied area.

\begin{tabular}{|c|c|c|c|c|c|c|c|c|c|c|}
\hline \multirow{2}{*}{ 空 } & \multirow{2}{*}{ Profiles } & \multirow{2}{*}{$\begin{array}{l}\text { Depth } \\
(\mathrm{cm})\end{array}$} & \multicolumn{4}{|c|}{$\begin{array}{l}\text { Available macro nutrients } \\
\left(\mathrm{mg} \mathrm{kg}^{-1}\right)\end{array}$} & \multicolumn{4}{|c|}{$\begin{array}{c}\text { Available micro nutrients } \\
\left(\mathrm{mg} \mathrm{kg}^{-1}\right)\end{array}$} \\
\hline & & & $\mathrm{NO}_{3}$ & $\mathrm{NH}_{4}$ & $P$ & $\mathrm{~K}$ & $\mathrm{Fe}$ & $\mathrm{Mn}$ & $\mathrm{Zn}$ & $\mathrm{Cu}$ \\
\hline \multirow{12}{*}{ 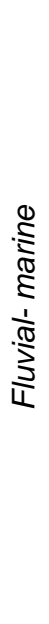 } & \multirow{4}{*}{ P1 } & \multirow{4}{*}{$\begin{array}{c}0-20 \\
20-45 \\
45-60 \\
60-80\end{array}$} & 41.90 & 32.40 & 15.40 & 330.72 & 9.81 & 3.22 & 0.27 & 1.24 \\
\hline & & & 76.95 & 36.45 & 16.80 & 298.42 & 3.53 & 1.75 & 0.24 & 1.54 \\
\hline & & & 38.47 & 31.73 & 21.00 & 304.98 & 2.00 & 3.00 & 0.43 & 1.40 \\
\hline & & & 72.27 & 15.53 & 14.50 & 291.72 & 4.35 & 1.42 & 0.27 & 0.67 \\
\hline & \multirow{4}{*}{ P2 } & \multirow{4}{*}{$\begin{array}{c}0.25 \\
25-55 \\
55-70 \\
70-90\end{array}$} & 77.00 & 29.70 & 20.20 & 360.20 & 8.71 & 0.87 & 0.21 & 3.13 \\
\hline & & & 87.10 & 30.38 & 16.20 & 366.44 & 4.61 & 0.73 & 0.17 & 4.74 \\
\hline & & & 125.55 & 36.45 & 15.40 & 291.72 & 4.04 & 0.73 & 0.17 & 3.00 \\
\hline & & & 126.22 & 38.48 & 16.10 & 156.00 & 6.04 & 0.70 & 0.18 & 3.01 \\
\hline & \multirow{4}{*}{ P3 } & \multirow{4}{*}{$\begin{array}{c}0-25 \\
25-60 \\
60-80 \\
80-130\end{array}$} & 99.95 & 39.15 & 21.70 & 321.20 & 7.85 & 2.87 & 0.45 & 1.47 \\
\hline & & & 225.45 & 36.45 & 19.20 & 327.44 & 3.54 & 1.74 & 0.17 & 1.53 \\
\hline & & & 48.65 & 25.65 & 14.80 & 330.72 & 2.42 & 2.97 & 0.19 & 1.53 \\
\hline & & & 111.42 & 30.38 & 19.00 & 336.96 & 3.14 & 3.01 & 0.21 & 1.14 \\
\hline \multirow{12}{*}{ 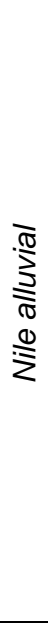 } & \multirow{4}{*}{ P4 } & \multirow{4}{*}{$\begin{array}{c}0-25 \\
25-60 \\
60-100 \\
100-130\end{array}$} & 64.17 & 37.13 & 10.90 & 421.20 & 9.81 & 1.24 & 0.31 & 1.99 \\
\hline & & & 122.80 & 35.10 & 18.50 & 291.72 & 4.01 & 0.69 & 0.30 & 2.01 \\
\hline & & & 72.90 & 37.80 & 13.70 & 156.00 & 4.01 & 0.71 & 0.24 & 1.67 \\
\hline & & & 84.37 & 39.83 & 14.50 & 207.48 & 4.01 & 1.31 & 0.24 & 1.42 \\
\hline & \multirow{4}{*}{ P5 } & \multirow{4}{*}{$\begin{array}{c}0-25 \\
25-45 \\
45-70 \\
70-130\end{array}$} & 123.52 & 46.58 & 19.10 & 356.46 & 5.41 & 3.24 & 0.40 & 2.42 \\
\hline & & & 99.90 & 40.50 & 17.70 & 389.22 & 4.21 & 3.00 & 0.21 & 1.78 \\
\hline & & & 82.35 & 41.85 & 14.40 & 272.22 & 4.00 & 2.14 & 0.24 & 1.74 \\
\hline & & & 54.72 & 38.48 & 14.60 & 291.72 & 3.57 & 1.37 & 0.33 & 1.23 \\
\hline & \multirow{4}{*}{ P6 } & \multirow{4}{*}{$\begin{array}{c}0-25 \\
25-50 \\
50-70 \\
70-120\end{array}$} & 55.32 & 0.01 & 17.60 & 201.24 & 5.24 & 1.37 & 0.44 & 3.00 \\
\hline & & & 48.97 & 29.35 & 20.90 & 149.76 & 3.47 & 0.74 & 0.36 & 1.52 \\
\hline & & & 57.39 & 34.83 & 18.60 & 162.24 & 7.00 & 0.89 & 0.30 & 1.50 \\
\hline & & & 51.24 & 0.01 & 18.80 & 130.26 & 4.74 & 1.27 & 0.18 & 1.50 \\
\hline \multirow{12}{*}{ 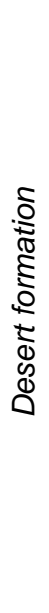 } & \multirow{4}{*}{ P7 } & \multirow{4}{*}{$\begin{array}{c}0-25 \\
25-40 \\
40-70 \\
70-110\end{array}$} & 49.10 & 40.45 & 21.80 & 237.42 & 1.07 & 0.46 & 0.14 & 1.24 \\
\hline & & & 49.08 & 39.40 & 18.10 & 214.96 & 0.34 & 0.42 & 0.11 & 0.38 \\
\hline & & & 24.03 & 36.00 & 25.70 & 236.96 & 0.26 & 0.39 & 0.11 & 0.36 \\
\hline & & & 24.03 & 36.05 & 20.60 & 250.22 & 0.54 & 0.20 & 0.06 & 0.49 \\
\hline & \multirow{4}{*}{ P8 } & \multirow{4}{*}{$\begin{array}{c}0-25 \\
25-55 \\
55-110 \\
110-140\end{array}$} & 48.10 & 37.10 & 18.90 & 222.18 & 1.24 & 0.34 & 0.17 & 1.10 \\
\hline & & & 24.03 & 34.23 & 19.90 & 224.48 & 1.16 & 0.23 & 0.14 & 0.57 \\
\hline & & & 36.00 & 36.05 & 24.60 & 191.26 & 2.00 & 0.23 & 0.12 & 0.91 \\
\hline & & & 34.44 & 36.05 & 20.30 & 143.52 & 1.55 & 0.23 & 0.11 & 0.90 \\
\hline & & & 36.05 & 36.00 & 29.50 & 262.22 & 1.75 & 0.50 & 0.23 & 0.65 \\
\hline & pg & $20-40$ & 36.42 & 21.63 & 21.10 & 234.00 & 1.28 & 0.47 & 0.18 & 1.17 \\
\hline & 10 & $40-$ & 36.00 & 12.10 & 29.60 & 252.22 & 2.00 & 0.44 & 0.17 & 0.75 \\
\hline & & & 36.17 & 12.10 & 21.20 & 188.90 & 1.83 & 0.23 & 0.17 & 1.12 \\
\hline
\end{tabular}


El-Hassanin, et al.,

Table (5): Simulated and observed soil salinity and moisture of studied profiles.

\begin{tabular}{|c|c|c|c|c|c|c|}
\hline \multirow{2}{*}{ Units } & \multirow{2}{*}{ Profiles } & \multicolumn{2}{|c|}{ Soil salinity } & \multicolumn{2}{|c|}{ Soil moisture } & \multirow{2}{*}{$\begin{array}{l}\text { Irrigation } \\
\text { system }\end{array}$} \\
\hline & & Simulated & Observed & Simulated & Observed & \\
\hline \multirow{3}{*}{$\begin{array}{l}\text { Fluvial } \\
\text { marine }\end{array}$} & $\mathrm{P} 1$ & 8.41 & 7.79 & 0.10 & 0.06 & Basin \\
\hline & P2 & 3.02 & 2.84 & 0.31 & 0.21 & Basin \\
\hline & P3 & 3.95 & 3.00 & 0.22 & 0.20 & Basin \\
\hline \multirow{3}{*}{$\begin{array}{c}\text { Nile } \\
\text { alluvial }\end{array}$} & P4 & 1.93 & 1.57 & 0.52 & 0.49 & Basin \\
\hline & P5 & 0.72 & 0.65 & 0.39 & 0.34 & Basin \\
\hline & P6 & 0.71 & 0.63 & 0.44 & 0.40 & Basin \\
\hline \multirow{3}{*}{$\begin{array}{c}\text { Desert } \\
\text { formation }\end{array}$} & P7 & 4.95 & 3.67 & 0.71 & 0.65 & Pivot \\
\hline & P8 & 14.48 & 12.85 & 0.63 & 0.57 & Dropping \\
\hline & P9 & 3.72 & 2.22 & 0.53 & 0.40 & Pivot \\
\hline
\end{tabular}
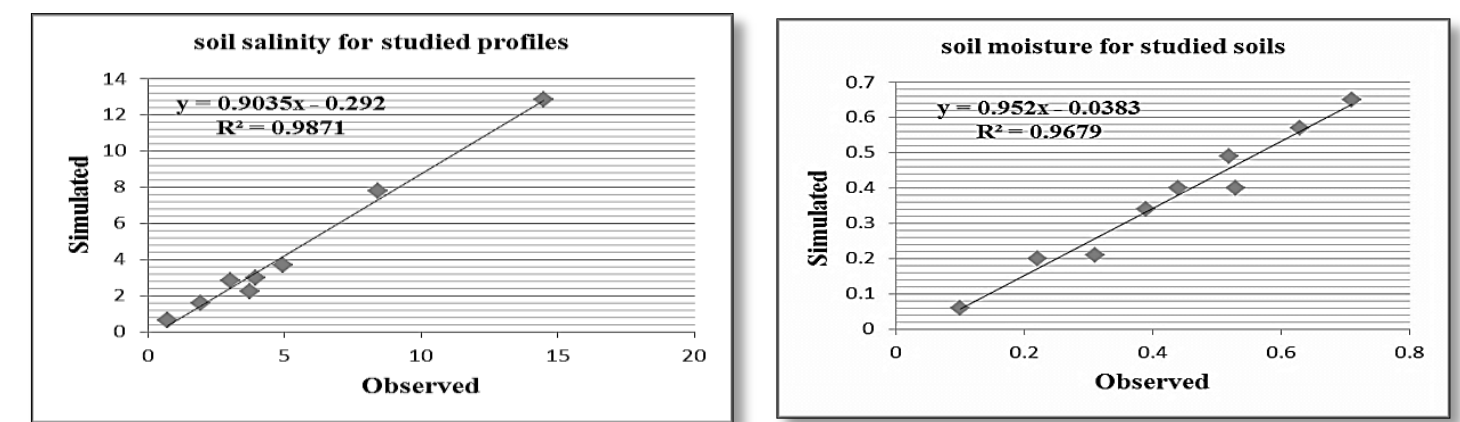

Figure (1): Comparison between all simulated and observed soil salinity and moisture under different irrigation systems for studied profiles. 

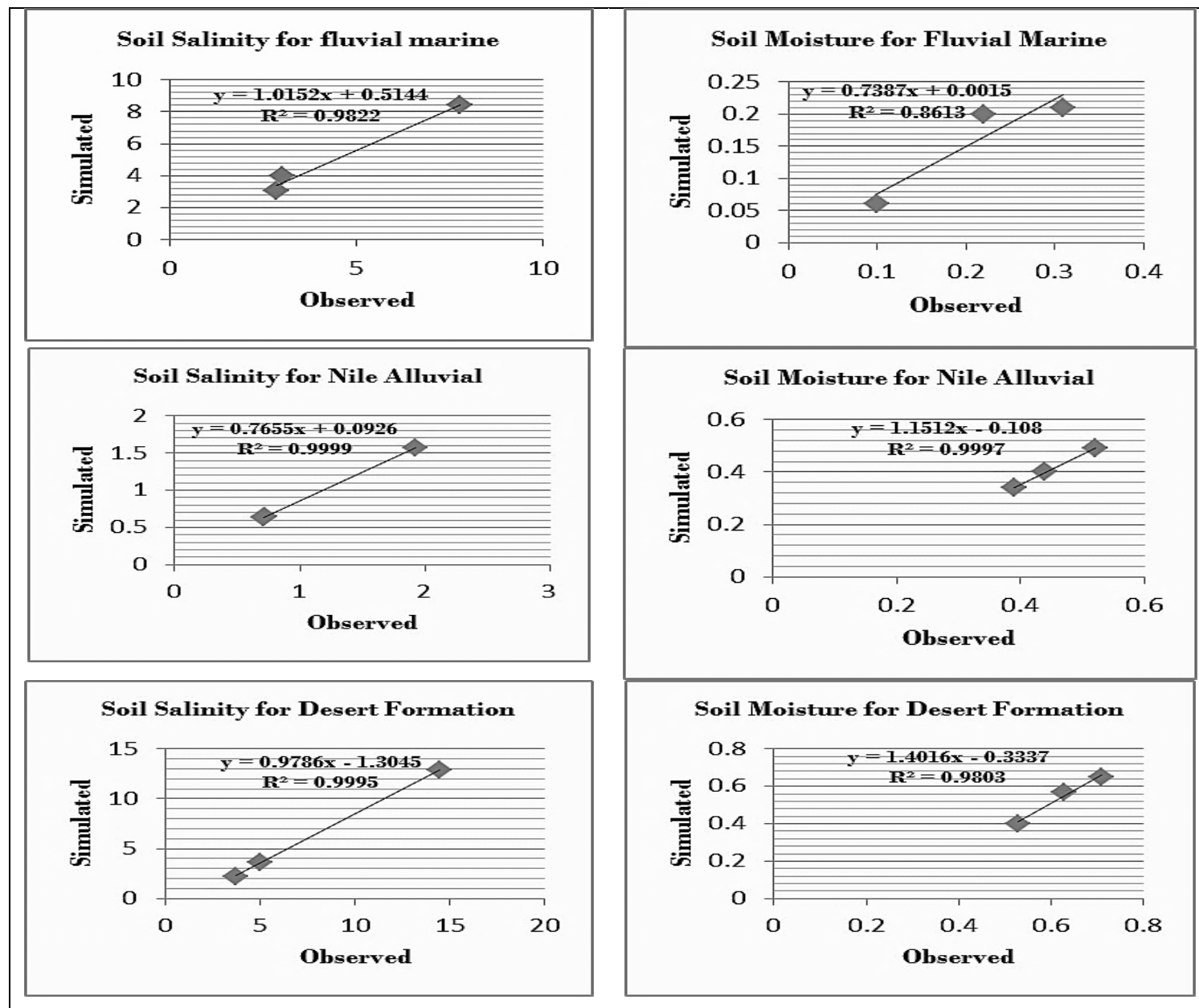

Figure (2): Comparison between simulated and observed soil salinity and moisture under different irrigation systems for physiographic units.

The model has been calibrated using the $100 \%$ fresh water in research. The calibration process was carried out first using the initial measured/estimated values of crop and soil parameters. The calibration has been carried using the same crop parameters for the three methods of irrigation. the model output is given as text and graphical files. These include horizontal and vertical distribution of soil moisture and soil salinity. The model's performance has also been assessed using different irrigation systems.

Profiles P1, P2, P3 (fluvial marine unit) were for a basin irrigation system with the different soil, same crop and climate input data. One can see from Figs. 3, 4 and 5 that there is slight to moderately accumulation of salts especially in the top layers.

Profiles P4, P5 and P6 (Nile alluvial unit) were for a basin irrigation system with the same soil, crop and climate input data. One can see from Figs. 6, 7 and 8 that there is slight accumulation of salts especially in the top layers.

Profiles P7, P8 and P9 (desert formation unit) were for a different irrigation system with the same soil, crop and climate input data. One can see from Figs. 9, 10 and 11 that there is moderately to high accumulation of salts especially in the top layers. 


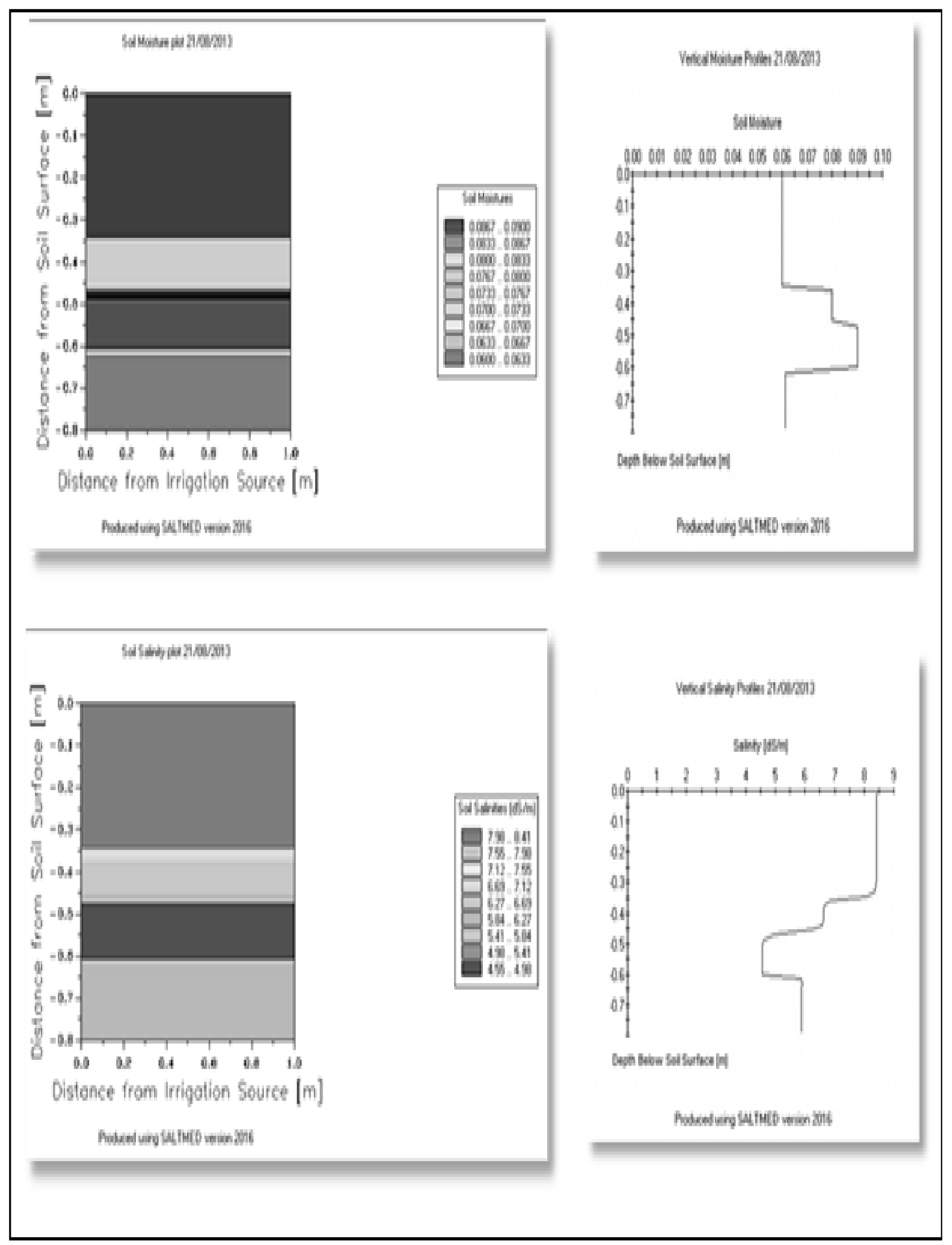

Figure (3): Vertical and lateral distribution of soil moisture and solil salinity in profile P1 under basin irigation. 


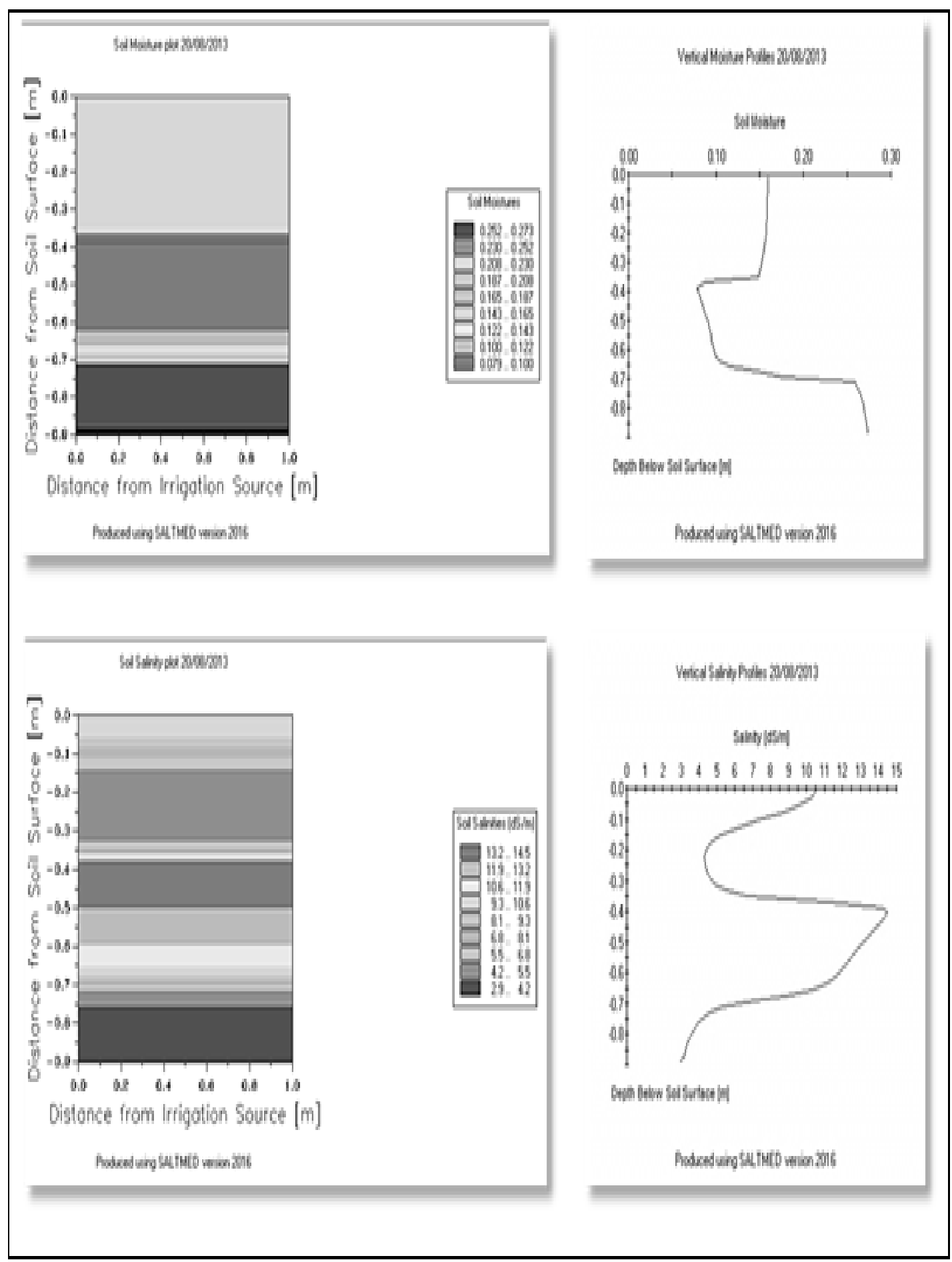

Figure (4): Veticial and lateral distribution of soil moisture and sol sal inity in profile P2 under basin irigagtion. 


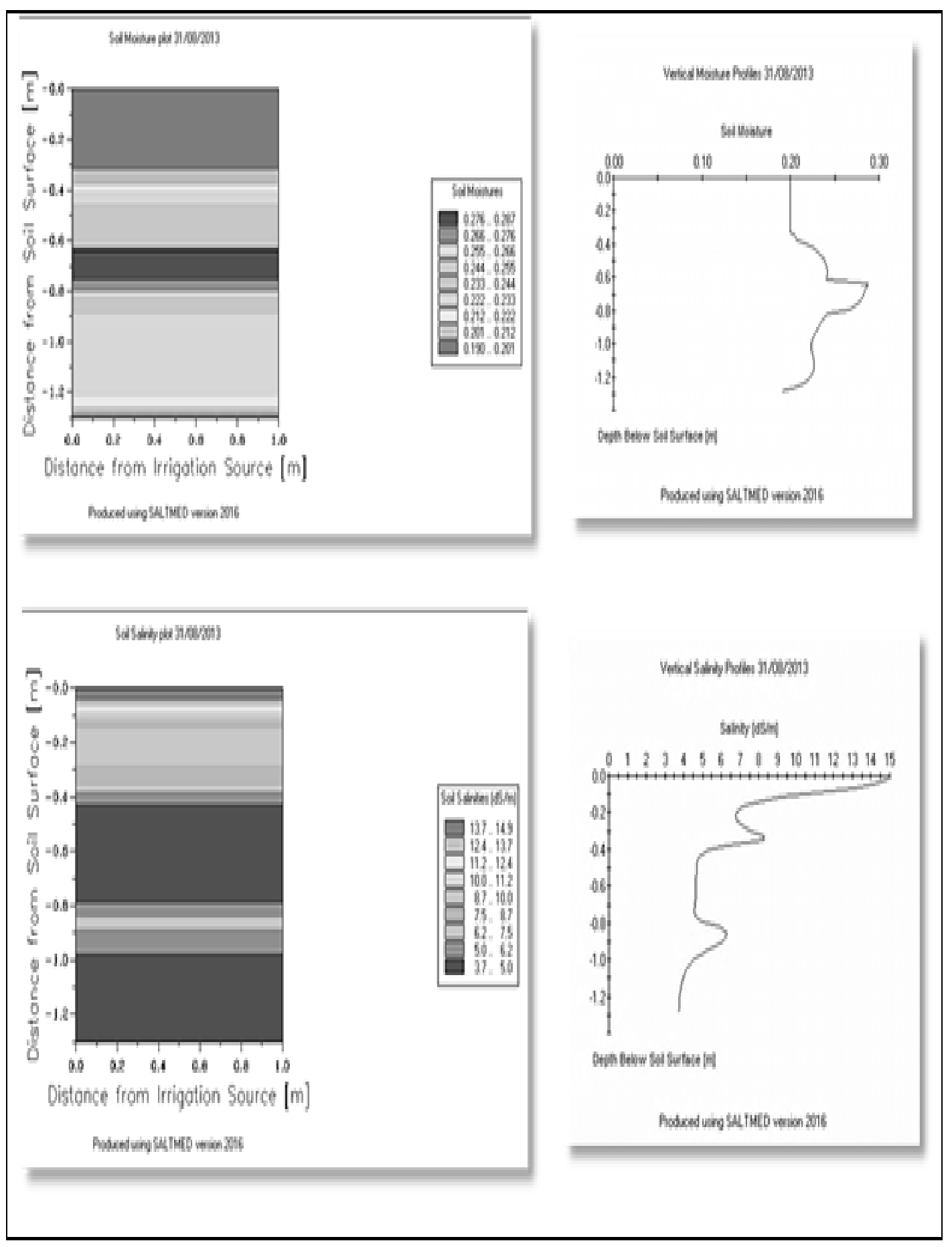

Figure (5): Vertical and lateral distribution of soil moisture and soil salinity in profile P3 under basin irrigation. 


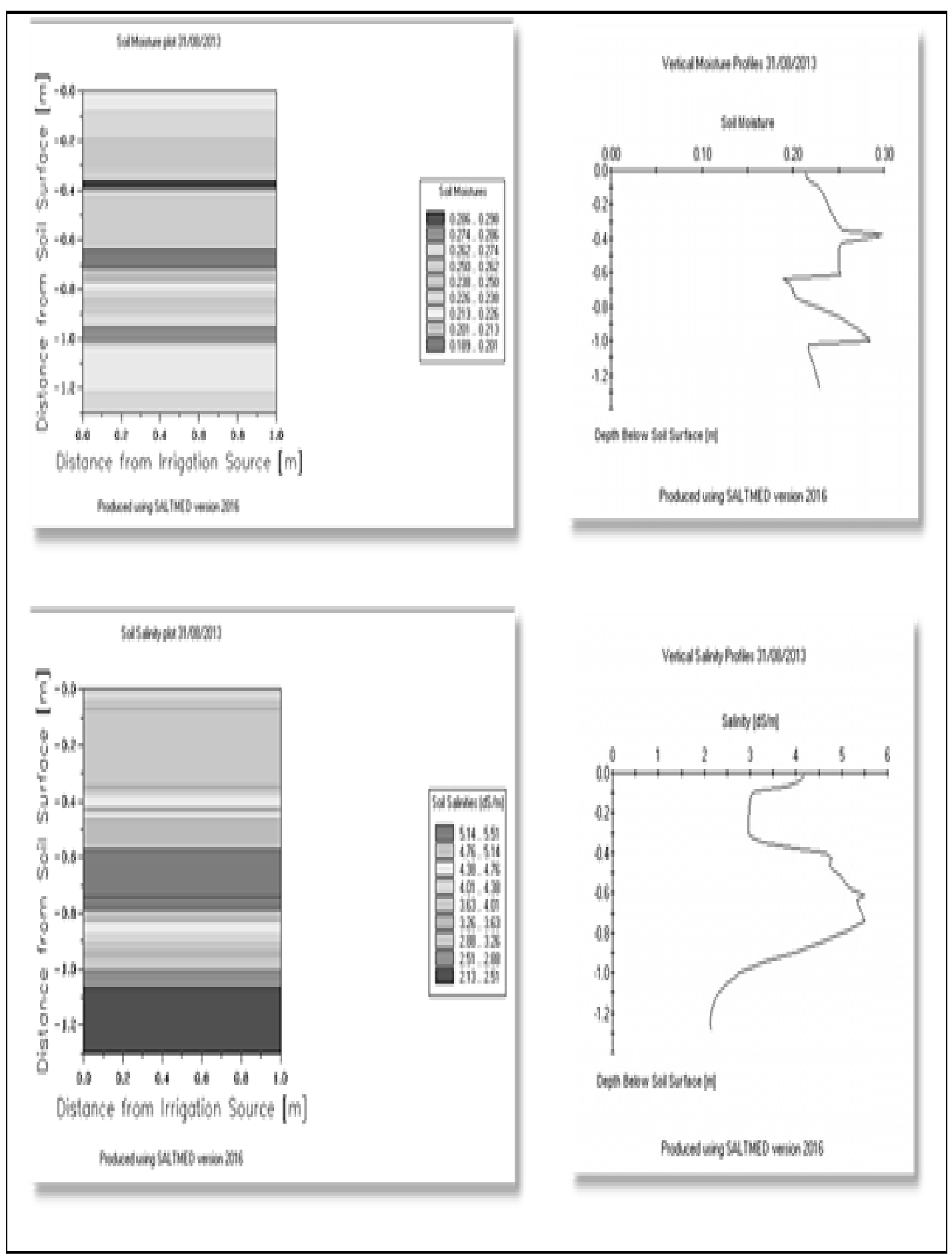

Figure (6): Vettical and lateral distribution of soil moisture and soil salinity in proffle P4 under basin iriggation. 
El-Hassanin, et al.,

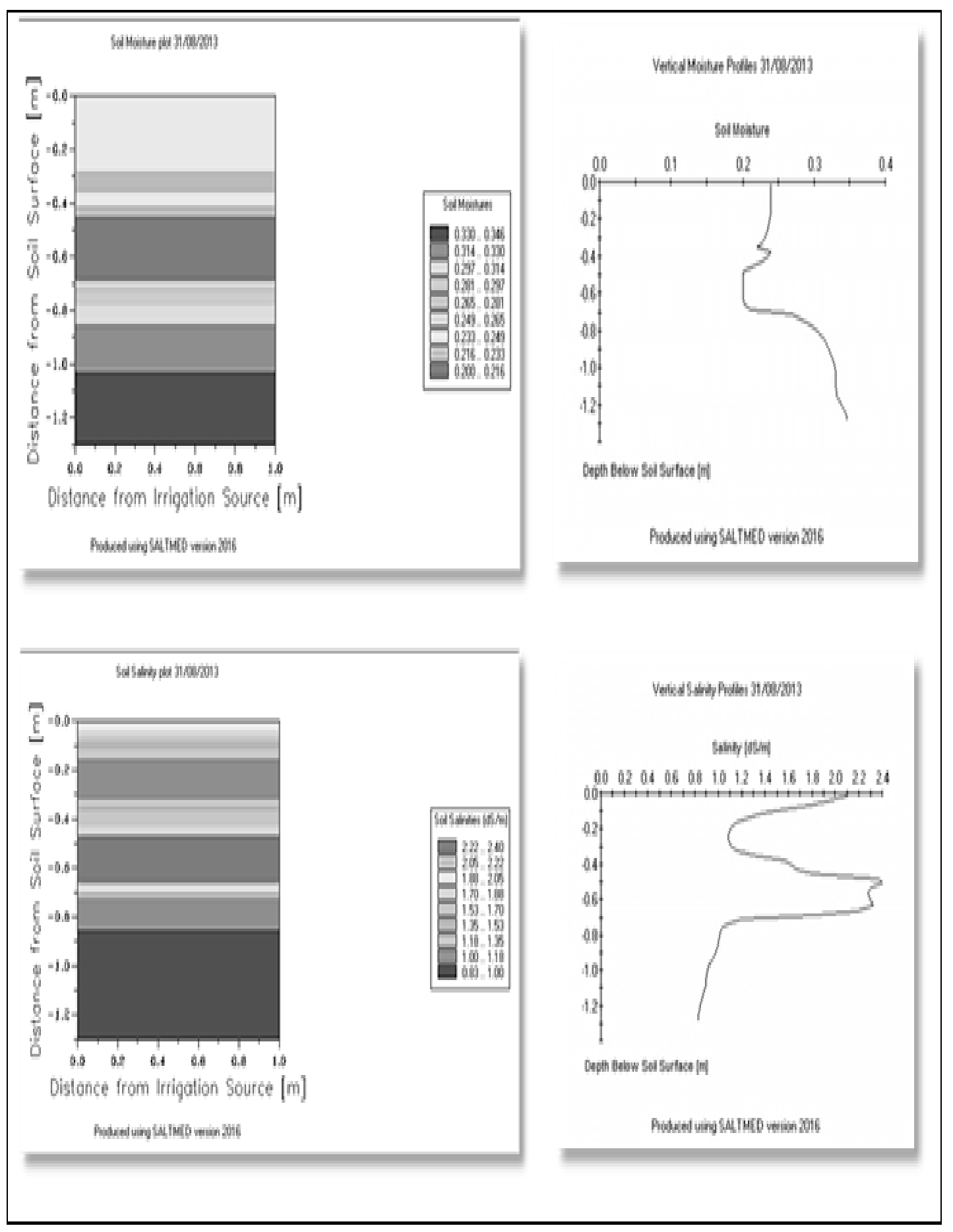

Figure (7): Vertical and lateral distribution of soll moisture and soil salinity in profile P5 under basin irivgation. 


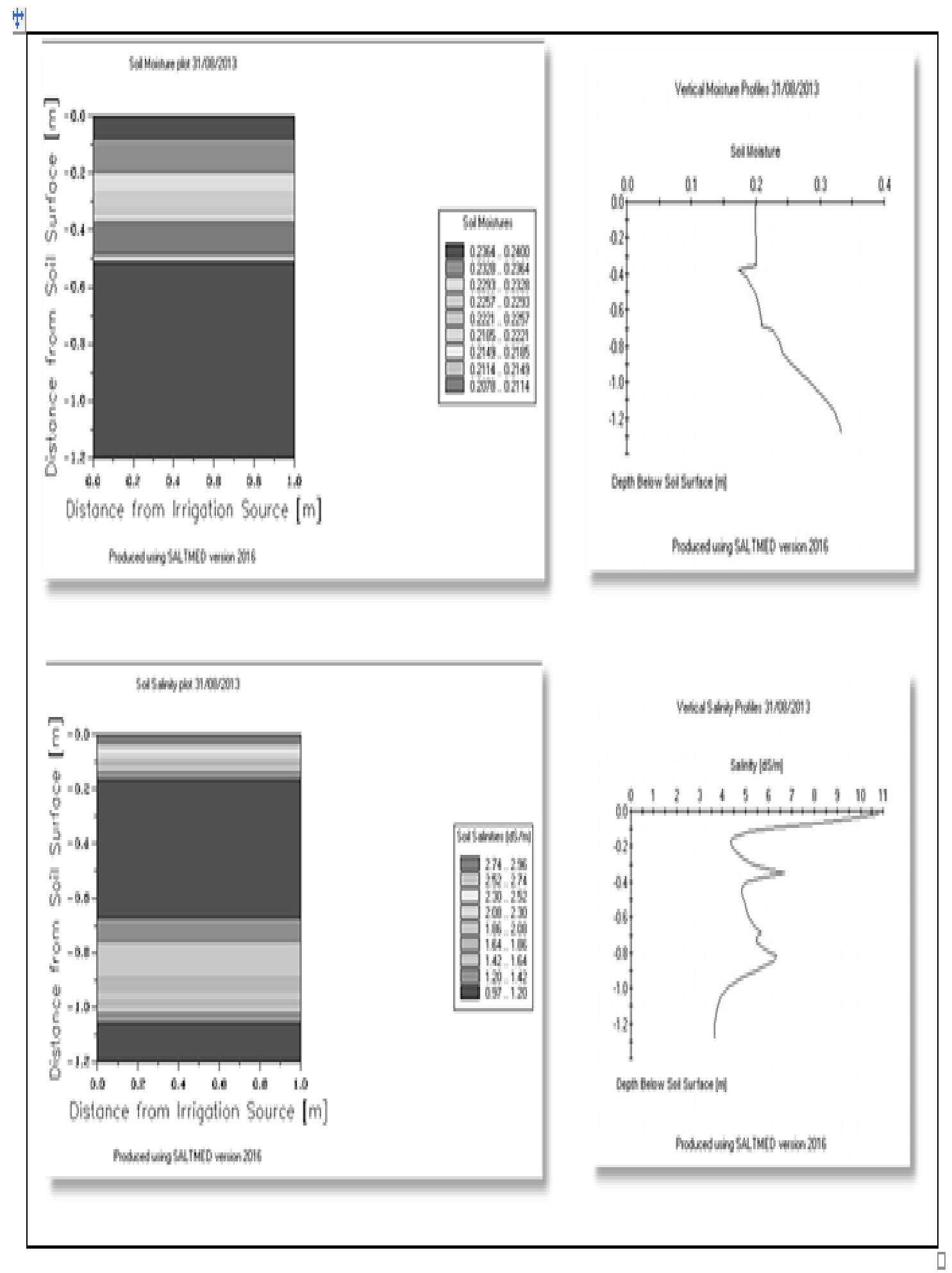

Figuree (8): Verticaland lateral distribution of soil moisture and soil salinity in proffle P6 under basin irivgation. 
El-Hassanin, et al.,

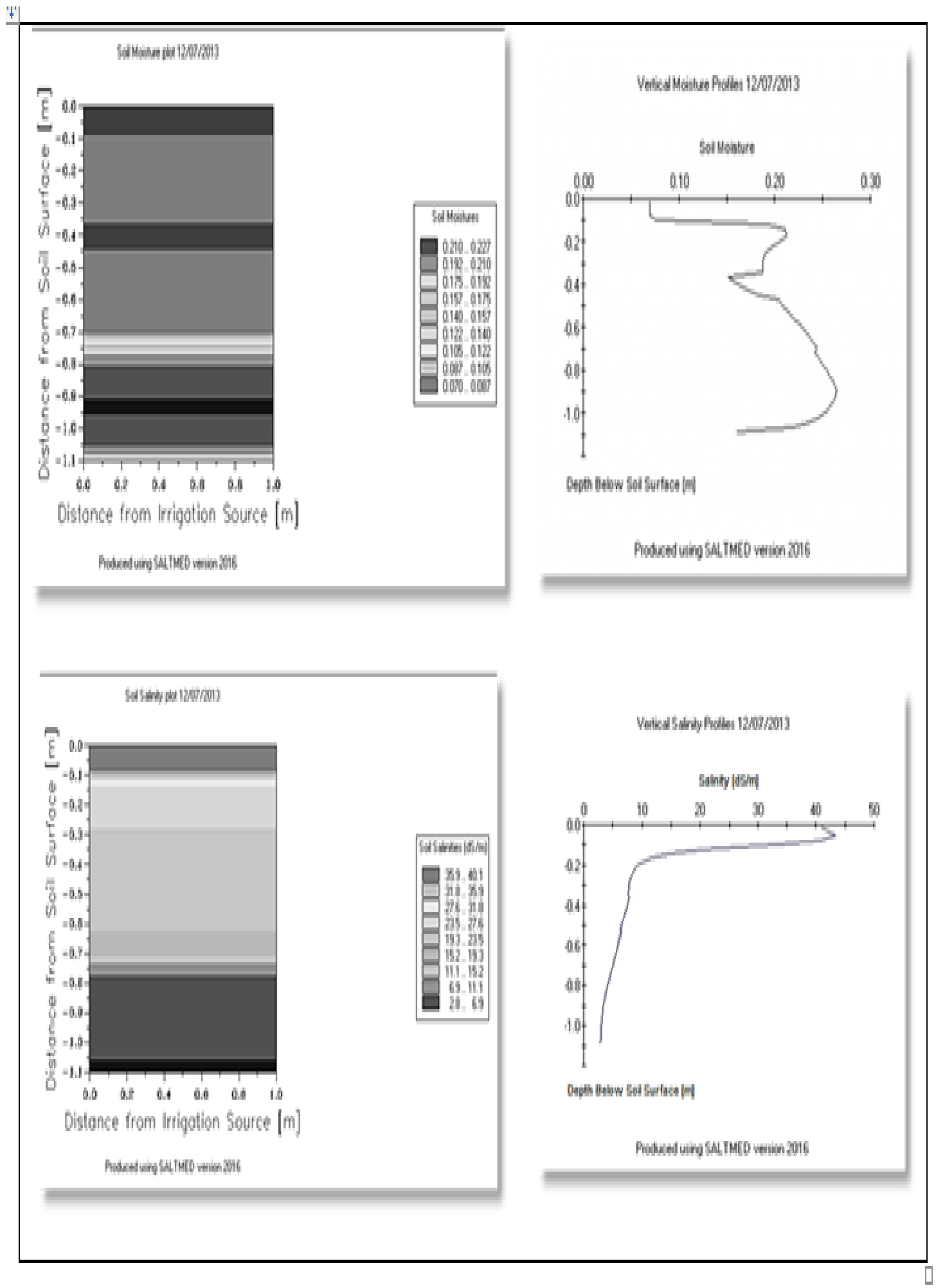

Figure (9): Vertical and lateral distribution of sol moisture and soil salinity in profile P7 under center pivot irivagation. 


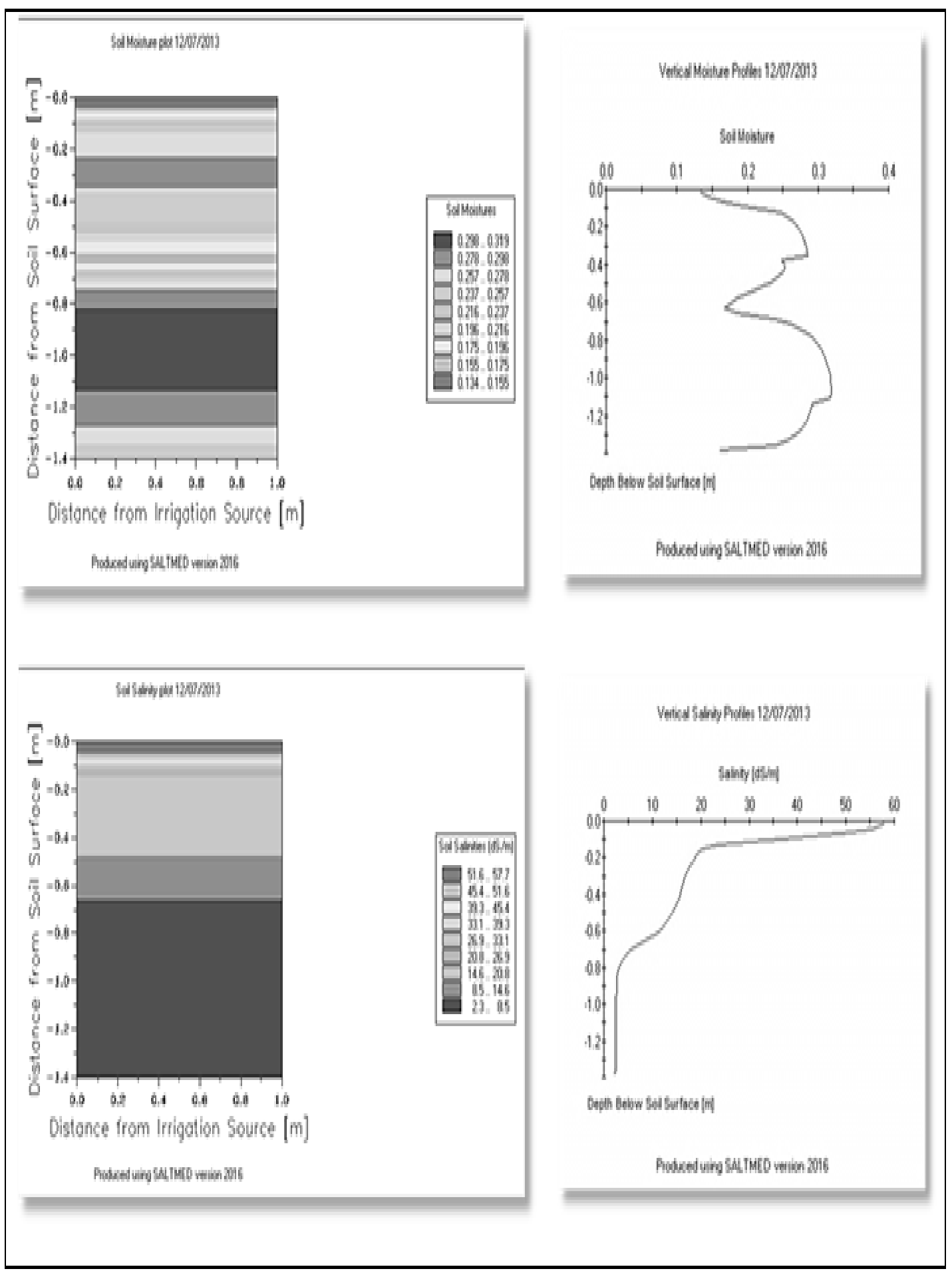

Figure (10); Vertical and lateral distribution of soil moisture and soil salinity in profile P8 under drip irrigation. 
El-Hassanin, et al.,

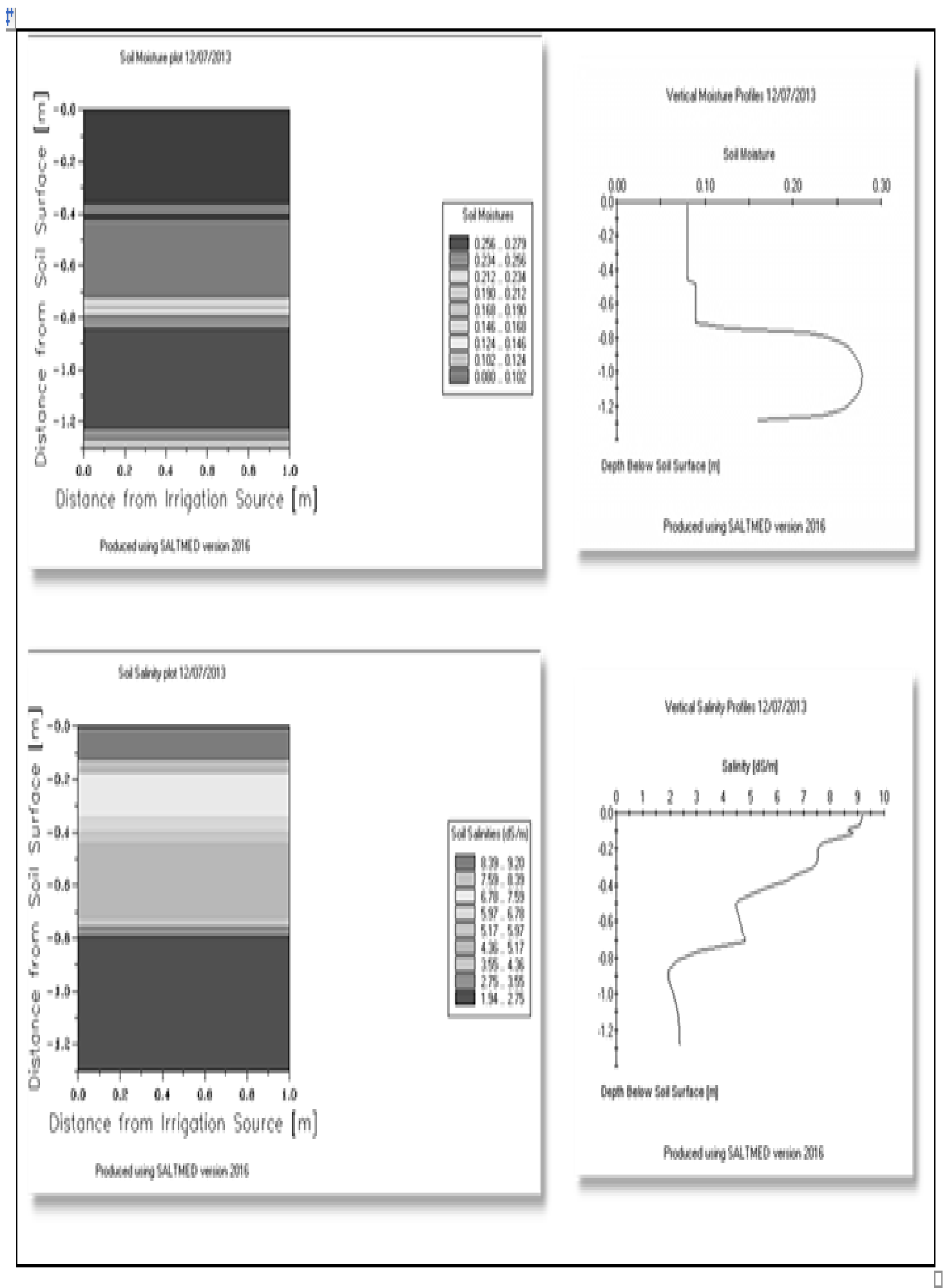

Figure (11): Vertical and lateral distribution of soil moisture and soil salinity in profile Pg under pivot irrigation. 


\section{CONCLUSIONS}

The results showed highly significant correlation between the observed and simulated data of salinity and moisture distributions in unit fluvial marine where, $R^{2}$ $=0.9822$ for soil salinity and $R^{2}=0.8613$ for soil moisture, in the unit of Nile alluvial $R^{2}=$ 0.9999 and soil moisture $R^{2}=0.9997$ in the unit desert formation $R^{2}=0.9995$ for soil salinity and $R^{2}=0.9803$ for soil moisture. SALTMED model identifies the soil chemical and physical characteristics, reflect the appropriate agricultural management systems under recently environmental changes. In the light of the model outputs, agricultural practices scenarios for soils and different crops such as the reform of agricultural practices (e.g. irrigation fertilization - adding organic matter), could be adapted.

\section{REFERENCES.}

Abou Kota, M. (2012). Distribution of salinity and nutrients in soils of Egypt and Tunisia under recently environmental changes. M. Sc. Thesis. Institute of African Research and Studies. Cairo Univ. Egypt.

Allen, G., L. Pereira, D. Raes and M. Smith (1998). Crop evapotranspiration, Irrigation and Drainage paper no. 56. FAO, Rome, Italy, $300 \mathrm{pp}$.

Allison, L., L. Richards, R. Reeve, L. Bernstem, A. Bower, J. Brown, M. Fireman, J. Hatcher, H. Hayward, G. Pearson and L. Wilcox (1954). Diagnosis and improvement of saline and alkali soils. Untied staff salinity laboratory staff. L.A. Richards (Editor). Agriculture Handbook: 60. U.S. Department of Agriculture.

Aly, S. (2005). Water quality appraisal for soil-water behavior in irrigated clay soil, Egypt. Ninth International Water Technology Conference (IWTC), Sharm El Shekh, Egypt.
Awad, M., F. Hammad, A. Aly and M. Sadek (1994). Use of environmental isotopes and hydrochemistry as indicators for the origin of groundwater resources in $\mathrm{El}$ Dabaa area, northwestern coastal zone of Egypt. Envir. Geochemistry and Health, 16(1): 31-38.

Black, C. (1965). Methods of Soil Analysis, Part I. Amer. Soc. Of Agronomy, Icn., Medison, Wisconsin, U.S.A.

Bower, C., R. Reitemeier and M. Fireman (1952). Exchangeable cation analysis of saline and alkali soils. Soil Sci. 73:251261.

Bresler, E. (1975). Two dimensional transport of solute during non-steady infiltration for a trickle source. Soil Sci. Soc. Am. Proc. 39: 604-613.

Cardon, E. and J. Letey (1992). Plant water uptake terms evaluated for soil water and solute movement models. Soil Sci. Soc. Am. J. 56: 1876-1880.

El-Nahal, M., R. Abd El-Aal, A. Abdel Wahid and I. Raafat (1977). Soil studies on the Nile Delta. Egypt. J. Soil Sci., 17:55-65.

FAO (1964). High dam soil survey, U.A.R. United Nations Development Program, Rome. Italy.

Fletcher Armstrong, C. and T. Wilson (1983). Computer model for moisture distribution in stratified soils under tickle source. Trans. ASAE 26: 1704-1709.

Follett, R. and W. Lindsay (1971). Changes in DTPA- extractable zinc, iron, manganese and copper in soils following fertilization. Soil Sci. Soc. Amer. Proc., 35: 600-607.

Guindy, K. (1989). Hydrogeology of the coastal zone between El Ameriya and El Hammam. Ph.D thesis, Fac. Sci., Ain Shams Univ., Cairo, p 151.

Hillel, D. (1977). Computer simulation of soil water dynamics; a compendium of recent work. IDRC, Otawa, Canada, 214pp.

Jackson, M. (1967). Soil chemical analysis. Prentic Hall, Ladia Private, LTD., New Delhi. 
Keeney, D. and D. Nelson (1982). Nitrogen - Inorganic forms. P.643-698. In: Methods of Soil Analysis, Part 2, A.L.

Klute, A. (1986). Methods of soil analysis, Part 1. Physical and Mineralogical Methods, $2^{\text {nd }}$ edition (Klute, A., ed.), Amer. Soc. Agronomy, Madison, Wisconsin, U.S.A.

Nur, A., M. Ezrin and W. Aimrun (2014). Relationship between soil apparent electric conductivity and $\mathrm{pH}$ value of Jawa series in oil palm plantation.

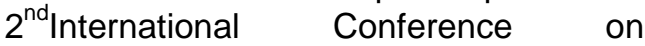
Agricultural and Food Engineering. 2: 199-206.

Olsen, S., C. Cole, F. Watanable and L. Dean (1954). Estimation of available phosphorus in soils by extraction with sodium bicarbonate. U.S. Dept. Agric. Circular No. 939.

Page, A., R. Miller and D. Keeney (Eds.) (1982). Methods of soil analysis. Part 2. Chemical and Microbiological Properties. $2^{\text {nd }}$ (Ed.). Amer. Soc. Of Agro., Madison, Wisconsin, USA.

Piper, C. (1950). Soil and Plant Analysis. Inter. Sci. Publisher, Inc., New York, USA.

Ragab, R. (2002). A holistic generic integrated for irrigation, crop and field management: the SALTMED model. Environ. Modell. Software 17: 345-361.

Ragab, R., J. Feyen and D. Hillel (1984). Simulating two-dimensional infiltration into sand from a trickle line source using the matric flux potential concept. Soil Sci. 137: 120-127.

Reitemeier, R. (1943). Semi microanalysis of saline soil solutions. Indus. And Engin. Chem., Analyt. Ed. 15:393-402.

Rhoades, J., F. Chanduvi and S. Lesch (1999). Soil salinity assessment: Methods and interpretation of electrical conductivity measurements. FAO Irrigation and Drainage Paper No.57-48.

Richards, L. (1948). Porous plate apparatus for measuring moisture retention and transmission by soil. Soil Sci. 66:105110.

Richards, L. (1954). Diagnosis and Improvement of Saline and Alkaline
Soils. United States Dept. of Agric., Handbook No. 60.

Schoonover, W. (1952). Examination of soils for alkali. University of California Extension Service, Berkeley, California (Mimeographed).

Shaaban, F. (2001). Vertical electrical soundings for groundwater investigation in northwestern Egypt: a case study in a coastal area. Journal of African Earth Sciences, 33(3-4): 673-686.

Sharaky, A., S. Atta, A. El Hassanein and K. Khallaf (2007). Hydro geochemistry of Groundwater in the Western Nile Delta Aquifers, Egypt, $2^{\text {nd }}$ International Conference on the Geology of Tethys, Cairo University.

Shata, A., M. El- Shazly, S. Attia and M. Aboul Fetouh (1978). The geology of quaternary deposits and their mutual relation to soil formation in the Fringes West of the Nile Delta, Egypt. Desert Inst. Bull., A.R.E., 28 (1): 43-77.

Simunek, J. and D. Suarez (1994). Twodimensional transport model for a variable saturated porous media with major chemistry. Water Res. Res. 30, 1115-1133.

Soil Survey Division Staff (1993). Soil survey laboratory information manual. Soil survey investigations report, No. 45. Version 1.0- 22:25.

Van Genuchten, M. Th. (1980). A closed form equation for predicting the hydraulic conductivity of unsaturated soils. Soil Sci. Soc. Am. J. 44: 892-898.

Van Reeuwijk, L. (1993). Procedures for Soil Analysis. CIP- Gegevens Koninklijke Bibliotheek, Den Haag, Wageningen: International Soil Reference and Information Centre. Technical Paper / International Soil Reference and Information Centre. ISSN 0923-3792: No. 9. Trefw.: Bodemkunde. ISRIC. Fourth Edition.

Williams, W. (1941). Rapid determination of potassium with dipicrylamine. Amer. Soc. Hort. Sci. Proc.39:47-50.

Wright, C. (1939). Soil Analysis. Thomas Murby Co., London. 


\section{التوزيع المكاني لملوحة التربة باستخدام برنامج SALTMED في

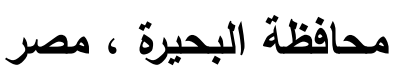

عادل سعد الحسنين(1) ، سامي عبد الجيد عبدالله (2) ، نجلاء صالح محمد (1) ،

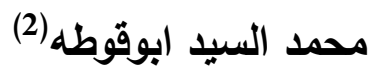

(1) معهد البحوث والدراسات الافريقية- جامعة القاهرة- مصر

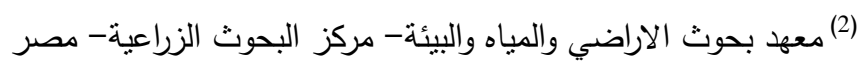

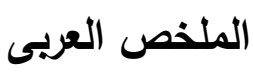

تعتبر مشكلة الملوحة شائعة للزراعة في البيئات الجافة ولها تأثثر كبير على إنتاجية التربة. وبالتالي، لذلك فانه

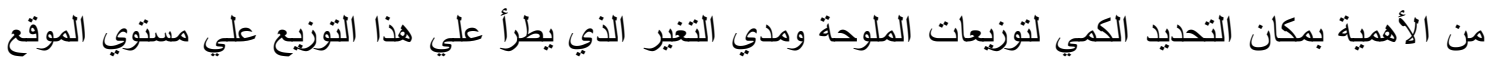

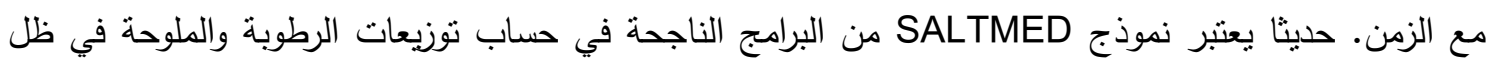
التغيرات البيئية. يعمل نموذج SALTMED تحت مختلف نظم الري واستراتيجياتها، وايضا نوعيات المياه المختلفة،

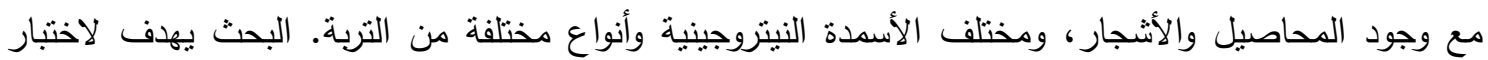
الموثوقية وقابلية تطبيق نموذج SALTMED في مجموعة واسعة من أنواع التربة المصرية. النموذج المستخدم في لوني تسعة نماذج من التربة تمثل ثناثة وحدات جيومرفولوجية، ومختلفة في الخصائص الفيزيائية والكيميائية، وذلك فئل

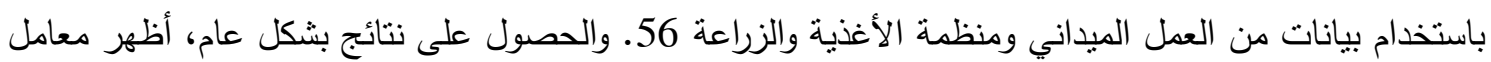

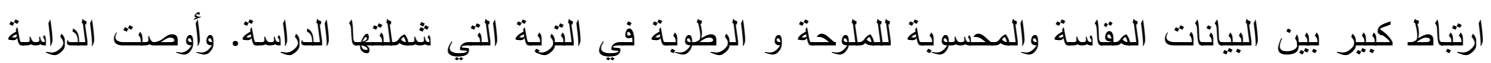
باستخدام نموذج SALTMED لتقدير رطوبة التربة وتوزيع ملوحة التربة لإدارة الممارسات والاستراتيجيات الزراعية الكلمات الافتتاحية: ملوحة التربة - محتوي الرطوبة - قوام التربة - برنامج SALTMED.

البريد الالكترونى

E-mail:mujareg@gmail.com

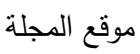

Mujareg.blogspot.com 
El-Hassanin, et al., 